\title{
Assessment of the Pressure Level over Lentic Waterbodies through the Estimation of Land Uses in the Catchment and Hydro-Morphological Alterations: The LUPLES Method
}

\author{
Daniel Morant ${ }^{1}\left(\mathbb{D}\right.$, Christian Perennou $^{2}$ and Antonio Camacho ${ }^{1, *(1)}$ \\ 1 Cavanilles Institute of Biodiversity and Evolutionary Biology, Universitat de València, 46980 Paterna, Spain; \\ daniel.morant@uv.es \\ 2 Institut de Recherche Pour la Conservation des Zones Humides Méditerranéennes-Tour du Valat, \\ 13200 Arles, France; perennou@tourduvalat.org \\ * Correspondence: antonio.camacho@uv.es; Tel.: +34-963543935
}

check for

updates

Citation: Morant, D.; Perennou, C.; Camacho, A. Assessment of the

Pressure Level over Lentic

Waterbodies through the Estimation of Land Uses in the Catchment and Hydro-Morphological Alterations: The LUPLES Method. Appl. Sci. 2021, 11, 1633. https://doi.org/10.3390/ app11041633

Academic Editor: Nir Krakauer

Received: 30 December 2020

Accepted: 8 February 2021

Published: 11 February 2021

Publisher's Note: MDPI stays neutral with regard to jurisdictional claims in published maps and institutional affiliations.

Copyright: (C) 2021 by the authors Licensee MDPI, Basel, Switzerland. This article is an open access article distributed under the terms and conditions of the Creative Commons Attribution (CC BY) license (https:/ / creativecommons.org/licenses/by/ $4.0 /)$.
Featured Application: The LUPLES method, explained in this paper, allows for the estimation of the level of pressures to which lentic waterbodies are exposed from land uses in the catchment area and direct alterations in their basin. The method can be used to approach the intensity of pressures and the possible effects of land uses in the catchment (and its changes) on the ecological status of lentic waterbodies, as having being validated by the correlation of the LUPLES estimated pressure levels with the metrics measuring impacts according to the Water Framework Directive.

Abstract: The features of lentic waterbodies largely depend on the surrounding environment. Mediterranean coastal lagoons have been historically altered, with their catchment being highly modified for agricultural, livestock, or urban uses. Changes in land uses induce pressures that impact the waterbodies and alter their ecological status. The objectives of this paper were: to develop a methodological approach (LUPLES: Land Uses for estimating Pressure Levels to approach the Ecological Status), to quantify the main pressures on the waterbodies and to forecast the possible impacts of these pressures on their ecological status. Corine-Land Cover maps and Geographic Information System technics were used to delineate and identify land uses in the catchments. Specific algorithms were created to quantify the main pressures from land uses in the catchment and hydro-morphological alterations in the immediate basin. The values of the estimated pressure levels were correlated with ecological status indicators using metrics developed for the European Water Framework Directive. Data were obtained from European and River Basin Authorities databases. Results showed statistically significant correlations between the pressure levels quantified by the LUPLES method and the impact level detected by biological, physical and chemical metrics. This method provides a useful approach to estimate the pressure levels affecting lentic waterbodies and could be applied to approach how they could affect their ecological status.

Keywords: GIS analysis; Mediterranean coastal lagoons; water pollution; ecological status; water framework directive; catchment areas

\section{Introduction}

Mediterranean lentic ecosystems (standing waters) have been historically altered [1], as pressures in their catchments can impact them to different degrees. These include changes from natural land uses to croplands or pastures for livestock [2], accompanied by increasing land reclamation to urban uses, especially in coastal areas [3]. The ecological quality of lentic ecosystems is largely influenced by their catchments, as runoff ends in the waterbody and largely determines its characteristics [4]. Organic matter, nutrients, sediments or specific pollutants can reach the waterbodies by runoff and diffuse sources [5]. 
In fact, constructed wetlands are used to retain or detoxify pesticides and other pollutants, and are used as water filters [6-8]. Therefore, any activity or change produced in the catchment may have direct effects on the waterbody $[9,10]$.

Both the estimation of direct impacts on hydrological and morphological features, as well as that of the indirect impacts based on the quantification of land uses causing alterations in water and sediment quality, provide a useful approach to assess the relationship between the waterbody and its environment [11,12]. Pressures linked to the pollution of waterbodies can have different effects depending on the land use and the type of activity in the catchment area, including eutrophication [13], increased organic pollution [14], acidification [15], or the release of specific pollutants [16], such as heavy metals, pesticides, antibiotics or other pharmaceutical and cosmetics products, the latter being among other so-called "priority substances" (Directive 2013/39/EC [17]). On the other hand, hydrological and morphological alterations both in the catchment and in the waterbody itself, represent specific pressures that can also alter the ecosystem ecological status.

The physical, chemical, biological, hydrological and morphological features of lentic ecosystems can change as a consequence of the impact caused by the increasing pressures promoted by land use and direct alterations. The changes in the ecosystem due to these pressures and alterations could lead to an impoverishment of the biological communities [18]. Consequently, the ecological structure and functioning of these waterbodies could be altered [19-21]. The relationship between the pressure level and the response of the system to these pressures (impacts) determines the degree of affection (impact) and the consequences on the ecological condition of the waterbodies.

The use of Earth Observation has shown to be an essential tool for ecosystem monitoring and assessment [22]; being especially useful for the mapping and identification of lentic ecosystems and their surrounding areas [23,24], as well as their hydrology [25] and assessment of their water quality [26,27]. Geographic Information Systems (GIS) techniques and available Copernicus products, such as the Corine-Land Cover maps [28,29], can be useful information sources that can be applied to provide estimations of pressures. Thus, these tools represent an approach for the ecological status assessment. There are other resources, such as SWOS (Satellite-based Wetland Observation Service), whose tools allow for the processing of images with several specific utilities; for example, the study the land uses in the catchment area of wetlands [30].

The pressure estimation methodology based on land uses may be used as a preliminary approach to forecast the ecological status of waterbodies, especially for those not included in monitoring networks, such as, for the case of Europe, most lentic ecosystems that are not declared as waterbodies following the European Water Framework Directive (WFD, Directive 2000/60/EC [31,32]). The correlation of the response of the ecological status metrics with the pressures level estimated from land uses and the determination of hydro-morphological alterations, may provide insights into how waterbodies respond to pressure levels, and might be extrapolated for waterbodies that are not well covered by monitoring networks, providing a direct ecological status assessment [33]. Pressure level identification could also be applied to conservation status assessment according to the Habitats Directive (HD, 92/43/EEC), not only for the structure and functions parameter but, specifically, also to provide an estimation of future prospects. All of this is especially plausible when products or tools showing the estimation of Land Uses and Land Uses Changes (LULUC), such as those available from Copernicus and SWOS, respectively, are available [34]. Therefore, land uses in the catchment area could be used as a proxy to approach the ecological health of lentic ecosystems in line with the assessment targets defined, for instance, by European regulation.

Assessment and monitoring of lentic ecosystems, however, can not only be restricted to waterbodies or protected habitats by European Directives, but could also be expanded to other aquatic ecosystems worldwide. This would be especially important in territories lacking monitoring networks of ecosystem status. The high cost of sampling and analysis, together with the lack of resources, make it difficult to control the status of many 
sites of ecological and social importance. For this reason, it is important to develop alternative methods of lower economic cost, which can be used as proxies to approach the status of aquatic systems, thus facilitating the use of the generated information to design management measures to protect natural features and ecosystem services.

The main aim of this work is to define a novel method, named LUPLES (Land Uses for estimating Pressure Levels to approach the Ecological Status), to estimate the pressure levels exerted on aquatic ecosystems using GIS tools, by identifying land uses and direct alterations in the catchment area. The influence of land uses in the catchments and the direct hydrological and morphological alterations are analyzed in order to unveil their relationship with the ecological status of the waterbodies. The relationships of the values of different biological, physical and chemical indicators used to measure the impacts-mostly considering metrics based on the WFD guidelines [31] — with the pressure levels assessed by our method, are addressed. The here defined method for pressure assessment could be used as a complementary tool for identifying indirect ways to approach to the measurement of the ecological status of waterbodies, as well as for the estimation of pressures driving ecological status in non-surveyed aquatic ecosystems.

\section{Materials and Methods}

\subsection{Study Sites}

The method developed consists of the application of two approaches to assess pollution and hydro-morphological pressures, respectively. A different set of study sites was used for the assay of these approaches. The first approach was based on the weighted assessment of the land uses in the catchment for the evaluation of pressures related to pollution, whereas the second approach evaluated the direct alterations of the hydro-morphological characteristics, both in the catchment area and in the waterbody immediate basin.

To explore the influence of land use on the determination of the pressure level and the consequent ecological status, 11 representative Mediterranean coastal lagoons distributed throughout the Mediterranean biogeographical region of Europe were selected (Figure 1). All of them are waterbodies declared under the national regulations deriving from the WFD and thus have information available on their ecological status indicators in European databases (Waterbase, [35]), collected by the European Environmental Agency (EEA), as well as by the River Basin Authorities, as monitored by the different member states (Table 1).

Hydrological and morphological pressures were assessed in a set of 43 waterbodies of different types, with available information on specific metrics based on macrophytes [36] (Table S1). Data on hydrological alterations were obtained from the Spanish inventory DATAGUA [37]. The assessment of morphological alterations was done using the geometrical calculation tools and high resolution orthophotos available on Google Earth Pro. References of the dates of the images used are in Table S1. The ecological status metric values assessing the hydrological and morphological impacts, based on submerged macrophytes or helophytes, respectively, were obtained from the River Basin Authorities of Spain (references in Table S2). 


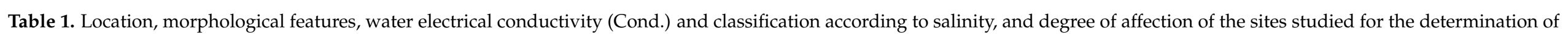

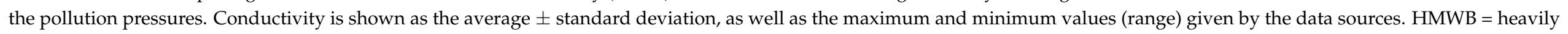
modified water body.

\begin{tabular}{|c|c|c|c|c|c|c|c|c|c|c|c|}
\hline $\begin{array}{l}\text { Mediterranean } \\
\text { Coastal Lagoons }\end{array}$ & Code & $\begin{array}{l}\text { EU Member } \\
\text { State }\end{array}$ & Longitude & Latitude & $\begin{array}{c}\text { Waterbody } \\
\text { Size } \\
\left(\mathrm{Km}^{2}\right)\end{array}$ & $\begin{array}{c}\text { Catchment } \\
\text { Area Size } \\
\left(\mathrm{Km}^{2}\right)\end{array}$ & $\begin{array}{l}\text { Cond. } \\
(\mathrm{mS} / \mathrm{cm})\end{array}$ & $\begin{array}{l}\text { Cond. Range } \\
\text { [min-max] } \\
(\mathrm{mS} / \mathrm{cm})\end{array}$ & Salinity & $\begin{array}{l}\text { Natural or } \\
\text { HMWB }\end{array}$ & $\begin{array}{l}\text { Conductivity } \\
\text { Data Source }\end{array}$ \\
\hline Albufera de València & ALBU & Spain & $000^{\circ} 21^{\prime} \mathrm{W}$ & $39^{\circ} 20^{\prime} \mathrm{N}$ & 27.0 & 769.7 & $2.1 \pm 0.5$ & $1.5-3.0$ & Freshwater & HMWB & [38] \\
\hline Etang de Biguglia & BIGU & France & $009^{\circ} 29^{\prime} \mathrm{E}$ & $42^{\circ} 36^{\prime} \mathrm{N}$ & 13.9 & 166.4 & $26.8 \pm 1.7$ & $24.5-28.4$ & Brackish & HMWB & [39] \\
\hline Stagno di Cábras & CABR & Italy & $008^{\circ} 29^{\prime} \mathrm{E}$ & $39^{\circ} 57^{\prime} \mathrm{N}$ & 21.0 & 436.5 & $14.4 \pm 4.9$ & $6.7-19.6$ & Brackish & $\mathrm{N} / \mathrm{A}$ & Waterbase [35] \\
\hline $\begin{array}{l}\text { Etangs de Canet et de } \\
\text { Villeneuve-de-la-Raho }\end{array}$ & CANE & France & $003^{\circ} 01^{\prime} \mathrm{E}$ & $42^{\circ} 40^{\prime} \mathrm{N}$ & 9.6 & 278.2 & $33.0 \pm 21.4$ & $7.8-60.5$ & Brackish & Natural & [40] \\
\hline $\begin{array}{l}\text { Valli residue del } \\
\text { comprensorio di } \\
\text { Comacchio }\end{array}$ & COMA & Italy & $012^{\circ} 11^{\prime} \mathrm{E}$ & $44^{\circ} 37^{\prime} \mathrm{N}$ & 115.9 & 7891.2 & $54.6 \pm 9.6$ & $44.5-77.3$ & Saline & $\mathrm{N} / \mathrm{A}$ & Waterbase [35] \\
\hline $\begin{array}{c}\text { Biviere di Gela } \\
\text { Stagno di Corru S'Ittiri }\end{array}$ & GELA & Italy & $014^{\circ} 20^{\prime} \mathrm{E}$ & $37^{\circ} 01^{\prime} \mathrm{N}$ & 0.8 & 74.6 & $3.5 \pm 0.9$ & $1.6-4.8$ & Freshwater & $\mathrm{N} / \mathrm{A}$ & [41] \\
\hline $\begin{array}{l}\text { Stagni di San Giovanni } \\
\text { e Marceddì }\end{array}$ & ITTI & Italy & $008^{\circ} 30^{\prime} \mathrm{E}$ & $39^{\circ} 44^{\prime} \mathrm{N}$ & 11.5 & 662.4 & $36.2 \pm 18.3$ & $1.1-63.9$ & Brackish & $\mathrm{N} / \mathrm{A}$ & Waterbase [35] \\
\hline Kotychi lagoon & KOTY & Greece & $021^{\circ} 17^{\prime} \mathrm{E}$ & $38^{\circ} 00^{\prime} \mathrm{N}$ & 4.4 & 478.2 & $24.3 \pm 7.8$ & $18.8-29.8$ & Brackish & $\mathrm{N} / \mathrm{A}$ & Waterbase [35] \\
\hline $\begin{array}{l}\text { Les Etangs littoraux de } \\
\text { la Narbonnaise }\end{array}$ & NARB & France & $003^{\circ} 03^{\prime} \mathrm{E}$ & $43^{\circ} 09^{\prime} \mathrm{N}$ & 55.2 & 664.2 & $55.6 \pm 7.2$ & $65.1-45.1$ & Saline & Natural & {$[40]$} \\
\hline Etang de Thau & THAU & France & $003^{\circ} 37^{\prime} \mathrm{E}$ & $43^{\circ} 23^{\prime} \mathrm{N}$ & 67.5 & 363.0 & $61.6 \pm 2.4$ & $58.2-64.3$ & Saline & Natural & [40] \\
\hline Etang d'Urbino & URBI & France & $009^{\circ} 29^{\prime} \mathrm{E}$ & $42^{\circ} 02^{\prime} \mathrm{N}$ & 7.3 & 43.5 & $57.6 \pm 6.5$ & $40.8-63.4$ & Saline & HMWB & [40] \\
\hline
\end{tabular}




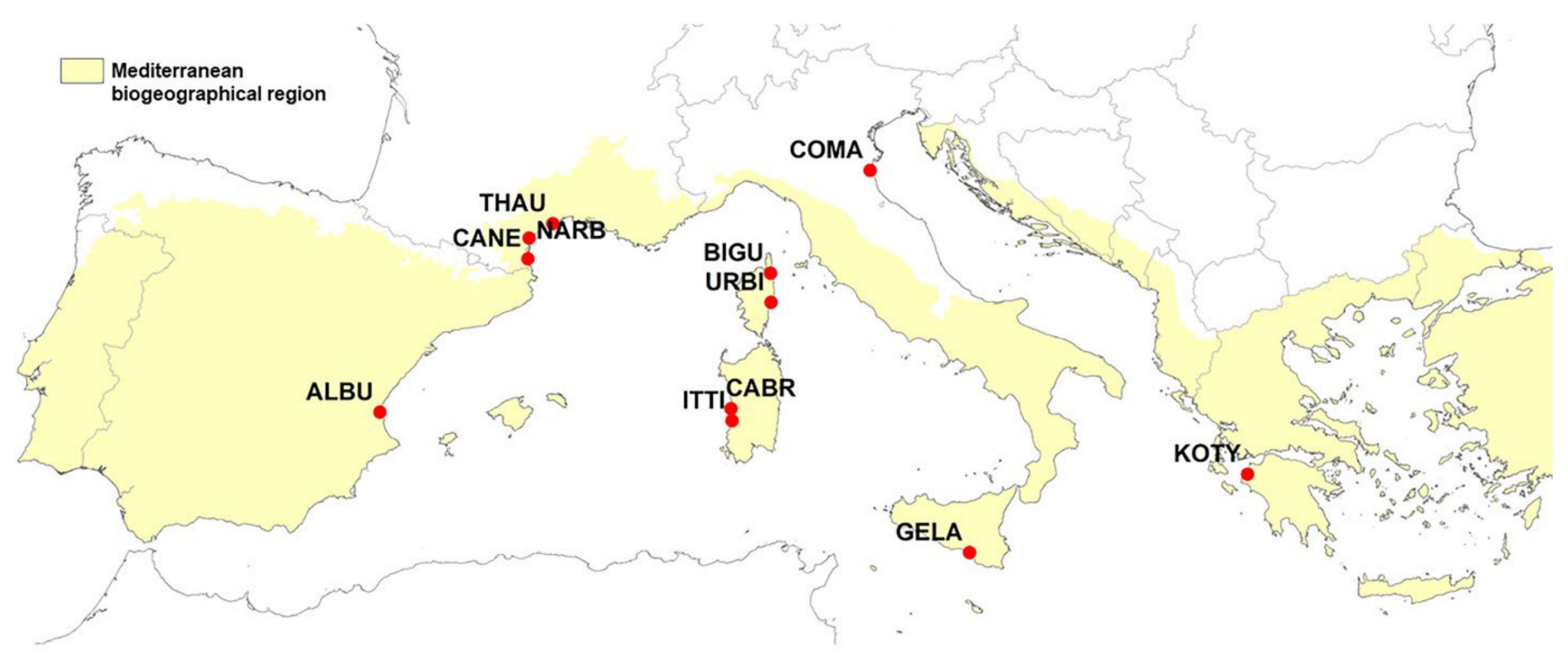

Figure 1. Map of the location of the waterbodies where land uses in the catchments were determined for pollution pressure estimation; all located within the European Mediterranean biogeographical region. The sites tested for hydro-morphological pressures are listed in Table S1.

\subsection{Catchment Area Delineation}

The catchment areas of the selected sites were defined by the procedures of a Geographic Resources Analysis Support System (GRASS) integrated into Q-GIS free software (Q-GIS 2.18.20 with GRASS 7.4.0.), using a Digital Elevation Model (DEM) raster, available in the Copernicus program [42]. Figure 2 details the steps taken for the loading of the DEM raster layer until obtaining the delineation of the watershed.

The lagoons BIGU, ITTI, THAU and NARB, presented more than one independent catchment area, e.g., north-south, according to the determination made by the GIS processes. As they are large lagoons or complexes, their catchments cover large areas and may be separated. Although the sum of all sub-catchments was considered as the total catchment area, the sub-catchments were kept separated for this study. This allowed for the separate assessment of land uses, and to correlate ecological status variables-with data from waterbody areas that were more heavily influenced by these inputs-with their corresponding pressure levels. For the rest of the cases, a single catchment area was defined for each coastal lagoon.

\subsection{Land Use Estimations}

In order to quantify the main pressures affecting each waterbody, land use within the waterbody catchment was analyzed using the delineation and classification of land uses according to the European Corine-Land Cover (CLC) [28]. Land use maps were accessed from the European Space Agency (ESA) CLC maps, v.20, year 2012, in Esri File Geodatabase (Esri-FGDB) vector format [29]. Using Q-GIS tools, the land use layer coincident with the delineated catchment of each lake was determined, then, the area of each land use class reflected in the CLC maps was calculated (Figure 3a).

\subsection{LUPLES Method for the Assessment of Pollution-Related Pressure Levels}

For the quantification of pollution pressures, the method developed, LUPLES (Land Uses for estimating Pressure Levels to approach the Ecological Status), is based on the quantification of the relative influence of land uses on the four main pressures related to 
pollution experienced by lentic ecosystems, namely: eutrophication, organic enrichment, acidification, and pollutant pressures.

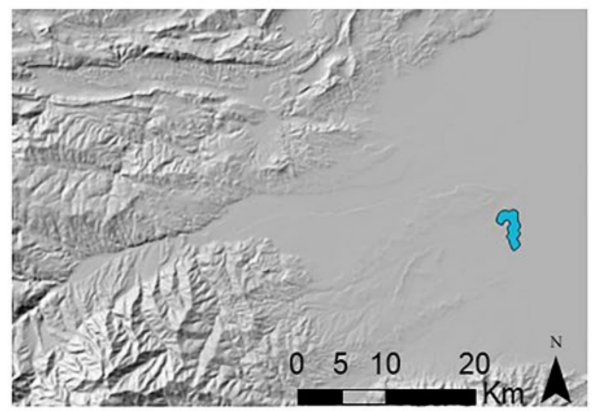

(a)

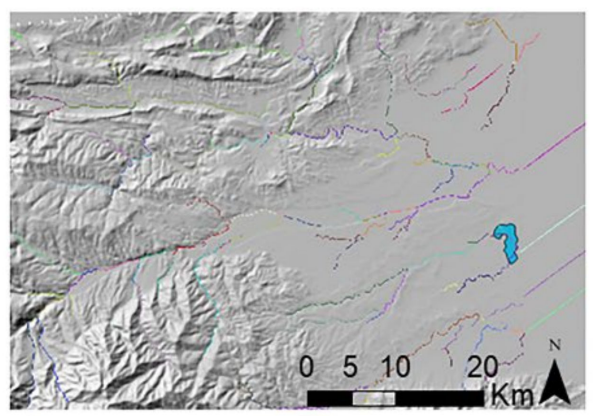

(d)

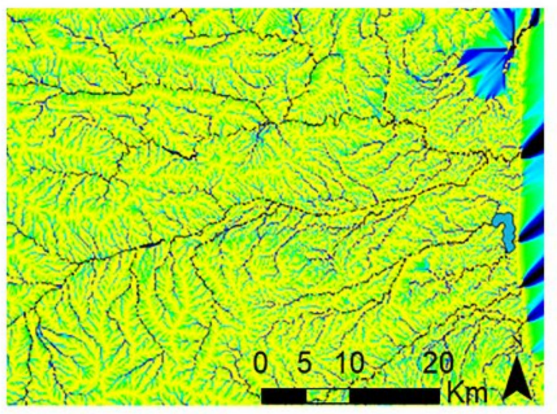

(b)

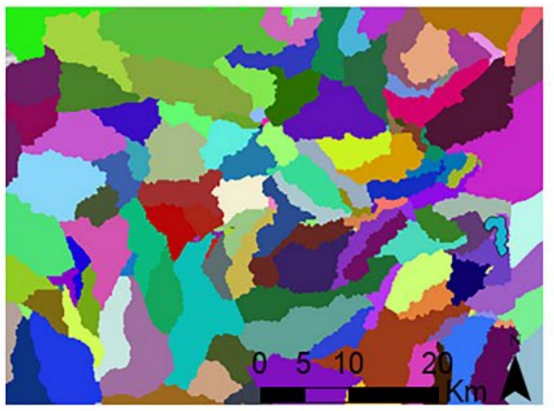

(e)

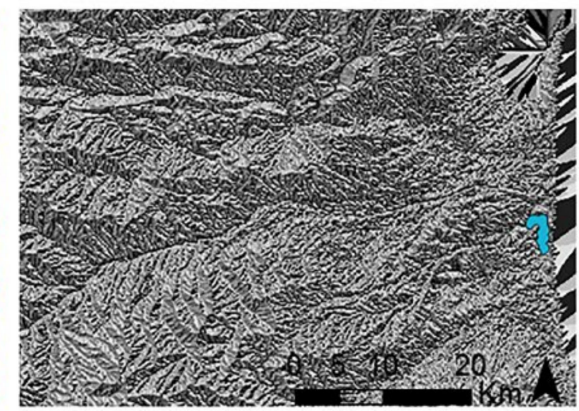

(c)

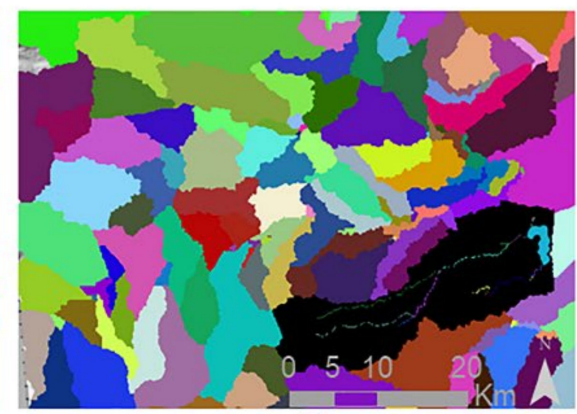

(f)

Figure 2. Steps followed for the delineation of the catchment area of the 11 studied coastal lagoons in Geographic Resources Analysis Support System (GRASS) Q-GIS, with the example of CANE (Etangs de Canet et de Villeneuve-de-la-Raho waterbody): (a) Digital Elevation Model (DEM) and coastal lagoon delineation; (b) flow accumulation map; (c) drainage direction map; (d) streams map; (e) sub-catchments map (minimum 2000 pixels per sub-catchments); (f) integration of sub-catchments and total catchment (in black).

Land uses were aggregated into groups from the different land cover uses that appear disaggregated at the third level category of CLC. Groups of land use of a similar type and incidence on each specific pressure were joined (Figure 3b). The groups were:

- Irrigated agriculture areas, such as rice fields, vegetables and fruit trees (CLC codes 212, 213 and 222).

- $\quad$ Rain-fed agriculture, including vineyards, olive groves, annual crops associated with permanent crops, mosaic crops, agricultural lands with significant natural and seminatural vegetation spaces, as well as agroforestry systems (CLC codes 211, 221, 223, 241, 242, 243, 244).

- Pressures exerted by livestock were estimated from land uses such as meadows and natural pastures (CLC codes 231 and 321).

- Urban uses by continuous and discontinuous urban structure, industrial and commercial areas, railways and associated land for these networks, port areas, airports, areas under construction, green urban areas, and sports and leisure facilities, which correspond to the CLC codes 111, 112, 121, 123, 124, 133, 141, 142, respectively.

- Finally, communication infrastructures (code 122), dumps (code 131), and mining areas (code 132) were also each mapped and assessed separately.

Natural uses were not considered for the pressure assessment due to their low impact regarding the pressures identified in comparison with the other land uses promoted by the human activities. 


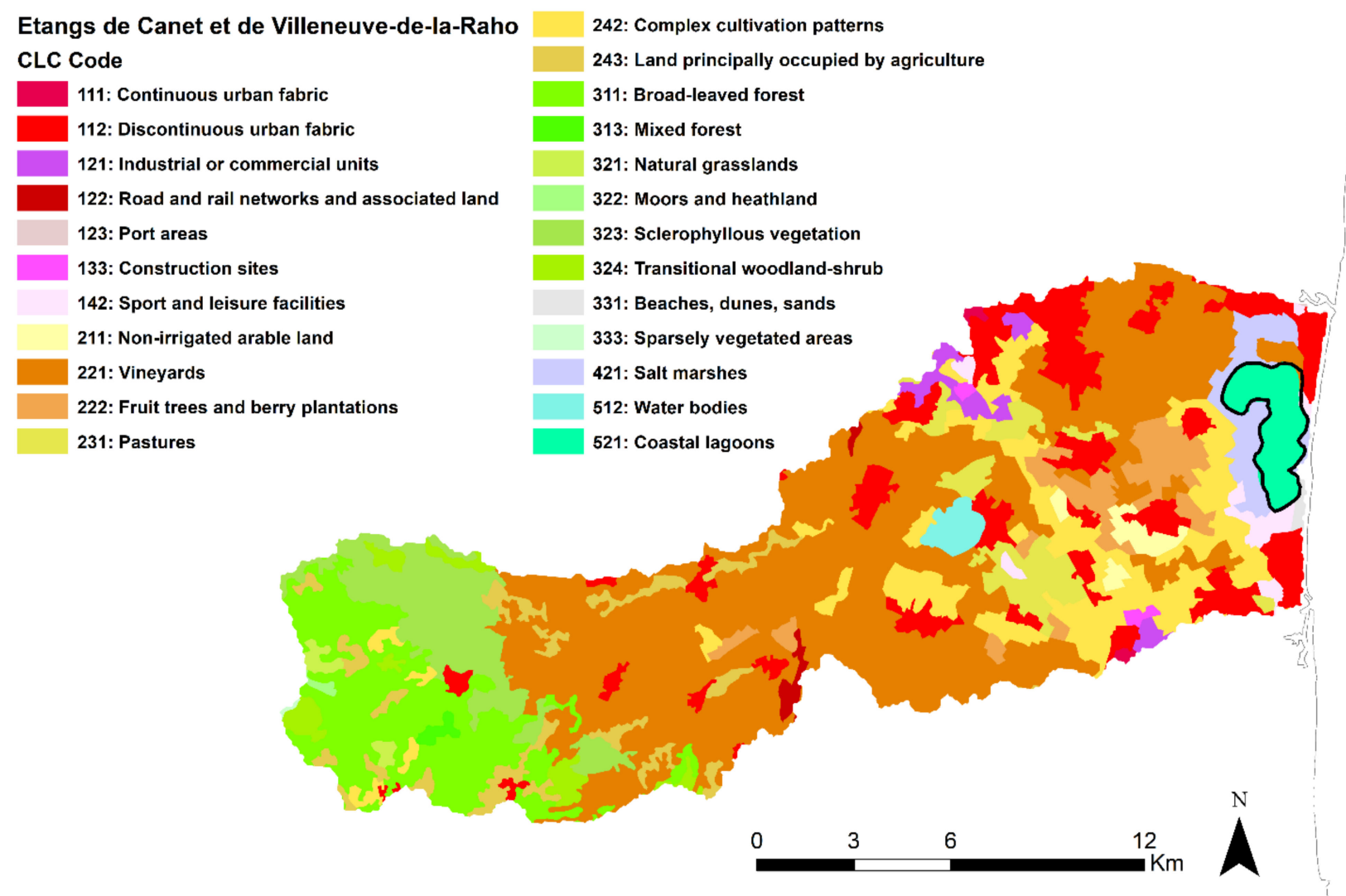

(a)

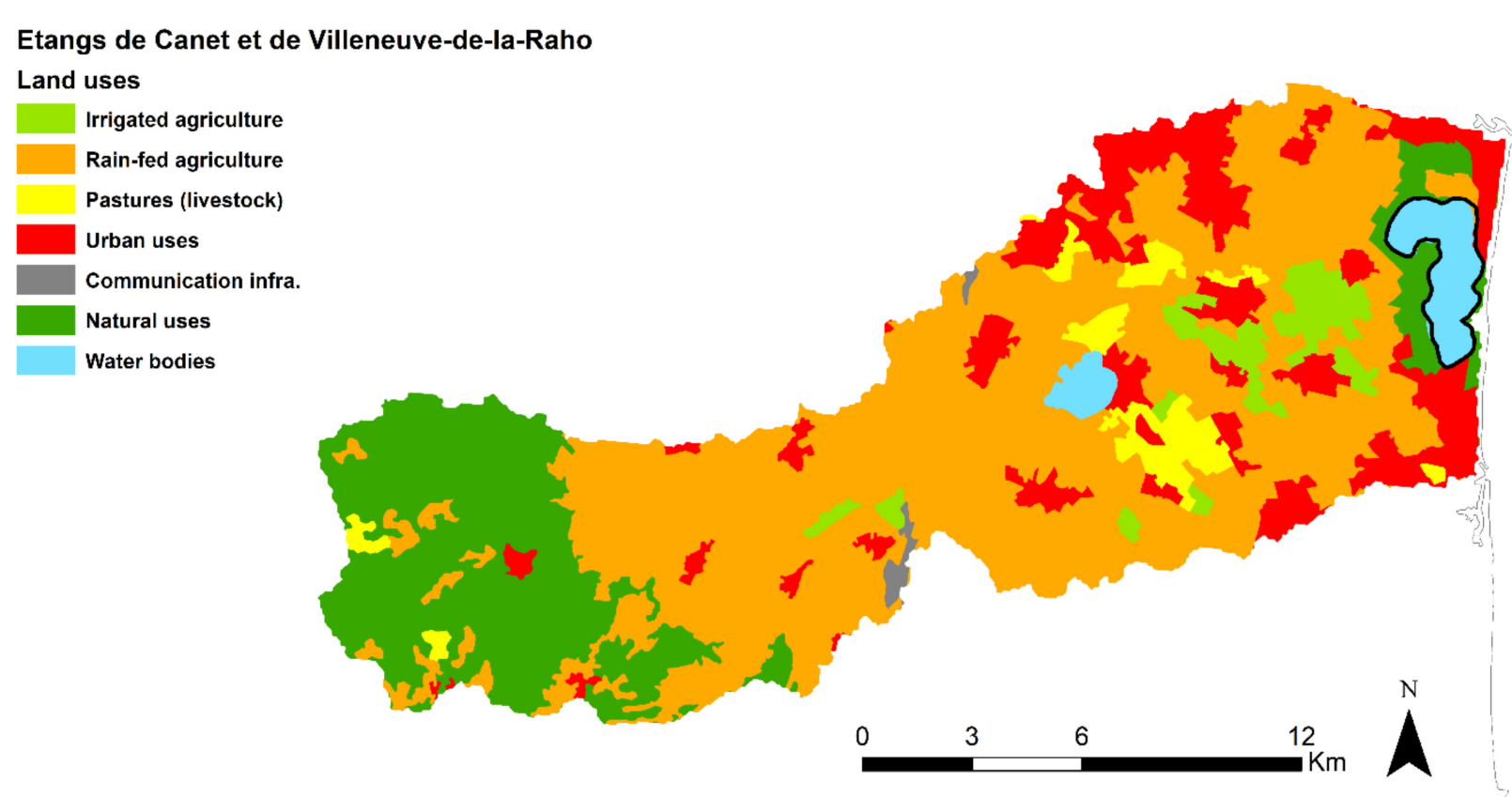

(b)

Figure 3. (a) Land uses obtained from Corine-Land Cover (CLC) in the catchment area of CANE (Etangs de Canet et de Villeneuve-de-la-Raho waterbody) (taken as an example). (b) Land uses joined by the land use groups established for the LUPLES (Land Uses for estimating Pressure Levels to approach the Ecological Status) method. Dumps and mining do not appear because their coverage is not relevant in the catchment of this lagoon. 
In order to normalize the data for their use as pressure estimations, the percentage of the area occupied by each of these land use groups regarding the total catchment is used, as follows (Equation (1)):

Land use pressure level $=\left[\left(\right.\right.$ Land use group area, $\left.\mathrm{km}^{2}\right) /\left(\right.$ Total catchment area, $\left.\left.\mathrm{km}^{2}\right)\right] \cdot 100$

Once the data for the areas of each land use type had been normalized, the relative contribution of each land use type to the level of each specific pressure related to pollution (eutrophication, organic enrichment, acidification and specific pollutants) was obtained for each of the studied coastal lagoons by using a weighting factor. Weighting factors were adjusted according to the relative influence of each land use on each defined pressure type, the later causing impacts on the waterbody. The weighting factor was assigned by ranking each land use over a range from 0 to 1 , as low (0.0 to 0.2$)$, middle (0.3 to 0.6$)$, and high ( 0.7 to 1$)$. The determination of the degree of contribution (specific weighting factor) of each land use to each pressure type was then fixed within these ranges based on the literature, mainly using technical reports on pressure evaluations and their impacts in lentic waterbodies [43], as well as scientific papers and monographies on the impact of the land uses causing the increases in the assessed pressures (e.g., [44-46] for eutrophication, [47] for organic enrichment, [48,49] for acidification, and [50-52] for pollutants).

To obtain the final pressure values, the percentage coverage of each relative area of the different land use groups in the catchment was multiplied by the associated weighting factor for the pressure type evaluated (eutrophication, organic enrichment, acidification and specific pollutants), then, these weighted relative contributions were added to sum up the pressure level of each waterbody for the specific pressure type. Table 2 summarizes the weighting factors used for the estimation of the contribution of each land use class to the different pressure type.

Table 2. Weighting factors applied for the quantification of the pressure type level for each land use group.

\begin{tabular}{ccccc}
\hline Land Use Group & Eutrophication & Organic Enrichment & Acidification & Specific Pollutants \\
\hline Irrigated agriculture & 0.8 & 0.2 & 0.0 & 0.7 \\
Rainfed agriculture & 0.3 & 0.1 & 0.0 & 0.3 \\
Pastures (livestock) & 0.3 & 0.4 & 0.3 & 0.5 \\
Urban uses & 0.4 & 0.6 & 0.2 & 0.5 \\
Communication infrastructures & 0.0 & 0.0 & 0.2 & 0.7 \\
Mining & 0.0 & 0.0 & 0.8 & 0.9 \\
Dumps & 0.7 & & 0.8 \\
\hline
\end{tabular}

The weighting factors used for the calculation of the eutrophication pressure level consider the contribution of land use to nutrient runoff to the waterbody [44-46]. Irrigated agriculture is the land use type with stronger effects due to the use of fertilizers in agricultural practices [44]. Weighting for dumps is also high as they are an important source of inorganic nutrients. Less relevant, but also having an impact, rainfed agriculture and urban uses are also considered as they are potential sources of nutrients for the waterbodies [50]. Finally, meadows and pastures, which may be used for livestock feeding, are taken into account [46], but with a lower weighting because they are just indirect indicators of livestock activity.

With respect to organic enrichment, dumps are considered as one of the greatest sources for this pressure, because of their high content of organic matter that potentially may end up in the waterbody. Urban uses are also an important source of organic compounds when they are located in a waterbody catchment area [47] because wastewater and other waste could reach the waterbody. Pastures could also be considered as indirect sources of contamination due to livestock drops dragged by runoff towards the waterbody. Agriculture generates a lower pressure level in comparison to its effect on eutrophication, although with a higher impact of irrigation agriculture due to the wider water pollutant dispersal capacity. 
Regarding acidification, land use for dumps and mining are considered as more important than other land use types and could have a strong negative impact on this pressure $[48,49]$. Livestock, urban uses, and communication infrastructures could also contribute to acidification pressures [49].

Finally, the strongest source of pollution by priority and non-priority specific chemical pollutants is mainly linked to mining and dumps. Communication infrastructures, mainly roads, and urban uses could also exert important pressures due to the spillage of chemical substances. Livestock could also be an important source of some types of chemical substances, due to the use of drugs and hormones in farming. Agriculture may also contribute to this pressure type through the use of pesticides, representing one of the most common and extended sources of such types of pollutants [51,52].

Equations (2)-(5) summarize the application of the LUPLES method as a proxy for the pollution pressure level assessment for each group of defined pressures.

Eutrophication pressure level $=$ irrigated agr $* 0.8+$ rainfed agr $* 0.3+$ pastures $* 0.3+$ urban uses $* 0.4+$ dumps $* 0.7$

Organic Enrichment pressure level $=$ irrigated agr. $* 0.2+$ rainfed agr $* 0.1+$ pastures $* 0.4+$ urban uses $* 0.6+$ dumps $* 0.8$

Acidification pressure level $=$ pastures $* 0.3+$ urban uses $* 0.2+$ comun.infras. $* 0.2+\operatorname{mining} * 0.9+$ dumps $* 0.8$

Pollution pressure level $=$ irrigated agr. $* 0.7+$ rainfed agr. $* 0.3+$ pastures $* 0.5+$ urban uses $* 0.5+$ comun.infras. $* 0.7+$ mining $* 0.9+$ dumps $* 0.8$

Usual values could range from 0-10 (low pressure level), 10-20 (moderate pressure level), 20-30 (high pressure level), to >30 (very high pressure level).

\subsection{LUPLES Method for the Assessment of Hydrological and Morphological Pressure Levels}

In order to quantify the level of hydrological pressures experienced by the waterbody, both the water abstractions and consequent reductions in the normal volume, and the nonnatural contributions, as well as over damming by heightening of the waterbody basin, are considered. To define the pressure levels, in the case of abstractions and transferences, the volumes extracted or transferred are compared to the maximum volume of the waterbody (Equations (6) and (7)). For heightening, the height of the over damming is compared with the maximum depth, as indicated in Equation (8). Data for these direct alterations at the studied sites were obtained for the sites listed in Table S1, with information gathered from the Spanish inventory DATAGUA [37].

$$
\text { Abstractions }=\left(\text { Volume extrac., in } \mathrm{Hm}^{3}\right) /\left(\text { Max waterbody volume, in } \mathrm{Hm}^{3}\right)
$$

Transferences $=\left(\right.$ Volume transferred, in $\left.\mathrm{Hm}^{3}\right) /\left(\right.$ Max waterbody volume, in $\left.\mathrm{Hm}^{3}\right)$

Heightening $=($ Height of over damming, in $\mathrm{m}) /($ Max waterbody depth, in $\mathrm{m})$

To homogenize the scale of the hydrological pressure levels to the other types of pressures, the results of this quantification were normalized to percentage form. To do this, data obtained from the quotient of the corresponding formula were divided by the highest data reached for abstractions, transferences and heightening, respectively, in all of the studied sites. Then, the three homogenized data were added up in order to obtain a joint value for the hydrological pressure, ranking from 0 to 100\%, as shown in Equation (9).

Hydrological pressures level $=$ Abstractions + Transferences + Heightening

Morphological pressures were calculated directly from satellite image viewing tools, more specifically, using Google Earth Pro. These tools were especially useful for the identification and quantification of the anthropogenic alterations of the waterbody margins and banks. To visualize and determine the percentage of altered shore areas, orthophotos and the geometrical calculation tools of the Google Earth Pro viewer were used. Through this free viewer, the altered areas were identified with respect to the total perimeter of 
the waterbody. The percentage of altered margins was calculated from the perimeter by shoreline area altered, by modifications or constructions in the shore of the waterbody (Equation (10)). Sites studied were mostly the same as in the hydrological pressures section, all being waterbodies from Spain.

Morphological pressure level $=($ Longitude of modified margin, in $\mathrm{m}) /($ Total waterbody perimeter, in $\mathrm{m}) * 100$

\subsection{Validation of the Method with Ecological Status Metrics}

The results of the pressure levels assessed with the proposed method, were correlated with the available public data on the ecological status assessment by using the indicators (metrics) available in European databases [35] and the River Basin Authorities database (Table S2). Data for the Mediterranean coastal lagoons were obtained from available datasets in the European Environmental Agency resources [35]. The information used corresponds to the databases: "Waterbase—Lakes" (which included the data for CABR, GELA and ALBU sites, freshwater to brackish lagoons) and "Waterbase-Transitional, coastal and marine waters" (which included the brackish and saline lagoons). These data were obtained from disaggregated databases. Not all the lagoons had available information on every metrics studied. The physical and chemical variables (indicators) selected included concentrations of ammonium $\left(\mu \mathrm{mol} \mathrm{N} \mathrm{L}{ }^{-1}\right)$, dissolved oxygen $\left(\mu \mathrm{M} \mathrm{O}_{2} \mathrm{~L}^{-1}\right)$, nitrate $\left(\mu \mathrm{M} \mathrm{N} \mathrm{L}^{-1}\right)$, nitrite $\left(\mu \mathrm{M} \mathrm{N} \mathrm{L}^{-1}\right)$, orthophosphate $\left(\mu \mathrm{mol} \mathrm{P} \mathrm{L}{ }^{-1}\right)$, silica $\left(\mu \mathrm{M} \mathrm{Si} \mathrm{L}^{-1}\right)$, total nitrogen $\left(\mu \mathrm{M} \mathrm{N} \mathrm{L}^{-1}\right)$, and total phosphorus $\left(\mu \mathrm{M} \mathrm{P} \mathrm{L}^{-1}\right)$, although for some of them there were not enough data for a proper statistical analysis. The data sources and availability for these selected variables in the studied lagoons are shown in Tables S2 and S3.

As biological indicators, three main biological quality elements (BQE), described in the WFD, were selected. Phytoplankton abundance was used as a measure of the chlorophyll- $a$ concentration (chl- $a, \mu \mathrm{g} \mathrm{L}^{-1}$ ); this, as well as the macrophytes coverage and benthic fauna, were in all cases normalized as the Ecological Quality Ratios (EQR) (ranking between 0 to 1 , dividing classifications between bad, poor, moderate, good and high status). In terms of both macrophyte coverage and benthic fauna, little or no information was present in the European databases for the selected coastal lagoons. Therefore, these data were obtained from national reports on the ecological status of these waterbodies, according to the WFD, available from River Basin Authorities of Spain and France. Macrophyte BQE assessment for both member states was mainly based on the percentage of vegetation cover, the relative percentage of type-specific taxa, and the specific richness. Indices used for the benthic fauna in France were AMBI (AZTI Marine Biotic Index) and multivariate-AMBI (M-AMBI). AMBI is based on the relative abundance of the species of the benthic macrofauna classified in ecological groups, which represent different degrees of tolerance to the alteration of the environment. AMBI correlates with an anthropogenic index, in this case the $\%$ of organic matter in sediments (as indicated in the national reports included in Table S2). M-AMBI is obtained by factor analysis, from the AMBI, the specific richness $S$ and the diversity index $\mathrm{H}^{\prime}$. In Spain, the standardized benthic invertebrates index used for lentic waterbodies is the IBCAEL, that joins two indices assessing the taxonomic composition and the abundance of the benthic invertebrate assemblages. This index has also previously been demonstrated to be a good indicator of the ecological quality of lentic waterbodies [53]. References to the reports and websites from where the information was obtained, as well as to the protocols of the sampling and index determination, can be found in Table S2.

The results of the LUPLES method for quantifying the pressures of eutrophication, organic enrichment, acidification and toxic pollution in each coastal lagoon were correlated with the values of the quality indicators of the ecological status, to validate the method and determine the correlations. Each pressure level assessed, corresponding to each study site, was correlated with the available physical-chemical and biological disaggregated metric data. Since both replicates and data from different dates were considered, this increased the variability. As explained above, for sites with more than one independent catchment ending up in the waterbody (NARB, BIGU, ITTI, THAU), for each catchment data included for the correlations were correlated with the values of the metrics for the 
part of the waterbody most affected by each sub-catchment. When testing the method, all the studied waterbodies were used without splitting them into groups based on salinity (conductivity) levels: this is because a wide range of pressures is required in order to evaluate and determine significant trends in the response of the ecological status metrics to such pressures, which cannot be achieved when splitting into groups because the sample would be too small. However, in this sense, some assays did show similar trends for cases with large enough sample sizes (data not shown). Further work will be developed in the future for this purpose.

For validation of the hydrological and morphological pressures, the percentages of coverage by submerged and emerged macrophytes were used as metrics for assessing the impact of these pressures on the ecological status of the lentic waterbody. These metrics are approved for ecological status assessment in Spain for assessing hydro-morphological pressures $[36,43]$. Data used were provided by official sources of the Spanish River Basin Authorities (Table S2).

The Spearman correlation coefficient was used to determine the correlation between the pressure levels estimated from land uses and the metric values, since in most cases the data did not follow a normal distribution. For hydrological and morphological pressures, Pearson correlation coefficients were applied, as both studied variables (metric values and pressure levels) were continuous and fitted a normal distribution. In this case, each waterbody had a pressure level and a metric value, in contrast with the land use pressures, where each waterbody had a single pressure level per pressure type with multiple metric values. Linear regression models were also obtained for determining the response of the metric values to the pressure levels. Linear regressions were selected following the recommendations of the WFD when studying the relationship between pressures and assessed ecological status.

\section{Results}

\subsection{Estimation of Pressure Levels in Coastal Lagoons}

For the selected Mediterranean coastal lagoons, the relative coverage of the main groups of land uses in the catchment areas differed among sites (Figure 4), with a larger area of rainfed agriculture in most catchments. A clear predominance of irrigated agriculture was found for ALBU and KOTY. Urban uses were above $10 \%$ of the total catchment area only for ALBU, BIGU, CANE and THAU. Comparatively, other land uses, such as communication infrastructures, mining areas and dumps were scarcely represented in the catchments. In three of the studied lagoons, BIGU, NARB, URBI, natural land uses (forest, scrubs, other vegetated areas, bare rocks, beaches and water bodies) dominated, covering a greater surface area than the rest of the uses, classified according to CLC.

Pressure levels regarding eutrophication, organic enrichment, acidification, and toxic pollutants, were estimated (Table 3) using the LUPLES method, from land uses in the catchments of the studied coastal lagoons. These pressure values were then correlated with the metrics assessing the ecological status (Table 4). For lagoons with more than one catchment the location of the sampling points was considered in order to select which metrics data had to be correlated with pressure levels of the respective sub-catchment.

ALBU and KOTY, the sites with the highest relative area used for irrigated agriculture in their catchment, were those with the highest estimated levels of eutrophication pressure: above 40, as calculated by the LUPLES method (i.e., very high pressure level). Other sites, such as CANE, CABR, COMA, GELA or ITTY showed values above 20 for this pressure, also indicating a high pressure level. All the places presented values for eutrophication pressure above 10, and only the western basin of BIGU was below this threshold. Regarding the organic enrichment pressures, only ALBU showed values over 20, corresponding to a high pressure level, whereas the rest of the sites were around 10, with some of them even registering below this boundary level, indicating a low pressure level (i.e., ITTY, URBI, NARB center and south, and BIGU west). Acidification pressure was not significant in any studied site, with all the values being far below 10. Finally, pollutant pressures were 
estimated to be at the very high level (above 30) in ALBU and KOTY, the same lagoons that showed the highest eutrophication pressures, and again, only BIGU west was below 10 . When combining these pressures with the values of the physical, chemical and biological water indicator metrics, significant correlations were obtained (Table 4).
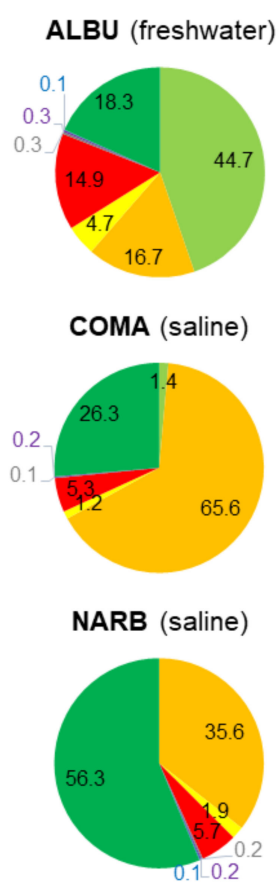
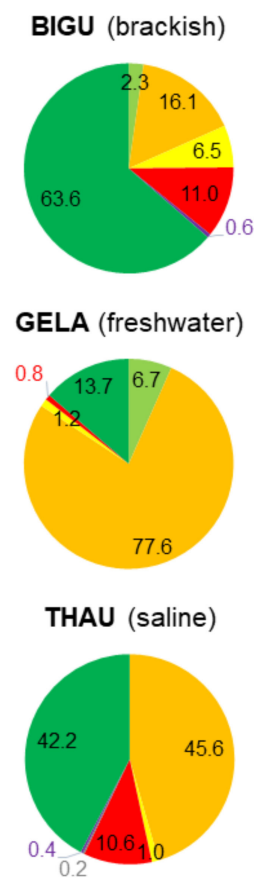
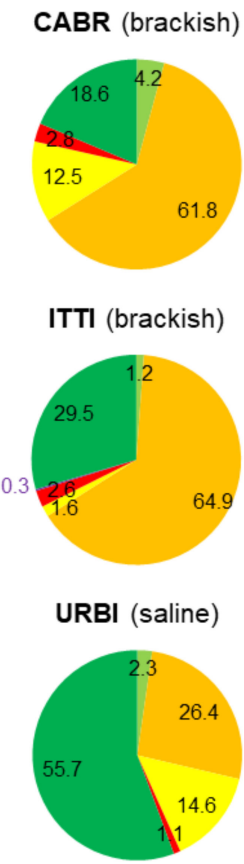

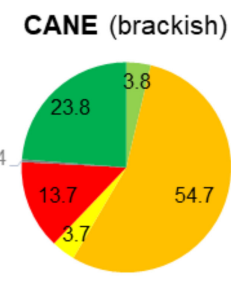

KOTY (brackish)

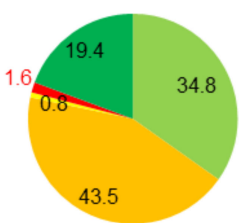

- Irrigated agrriculture «ain-fed agriculture Pastures (livestock) - Urban uses

- Communication infra.

- Mining areas

- Dumps

- Natural uses

Figure 4. Percentage of land uses from which the pressure levels were obtained for the whole catchment area of the studied coastal lagoons. BIGU, ITTI, NARB and THAU values show data for the whole catchment by the addition of the relative coverage in sub-catchment areas.

Table 3. Pressure levels estimated from the land uses in the catchment (or sub-catchment) areas for eutrophication, organic enrichment, acidification, and specific pollutants, using the LUPLES method, Equations (2) to (5). Pressure levels are categorized as low (green, 0-10), moderate (yellow, 10-20), high (orange, 20-30), and very high (red, >30).

\begin{tabular}{ccccc}
\hline Catchment Areas & Eutrophication Pressure & Organic Enrichment Pressure & Acidification Pressure & Specific Pollutants Pressure \\
\hline ALBU & 48.2 & 21.5 & 4.8 & 4.8 \\
BIGU center & 14.9 & 12.5 & 4.8 & 17.4 \\
BIGU north & 12.1 & 13.8 & 6.8 & 14.7 \\
BIGU south & 23.0 & 15.9 & 2.8 & 27.1 \\
BIGU west & 4.5 & 5.0 & 4.3 & 29.2 \\
CABR & 26.8 & 13.7 & 3.9 & 28.0 \\
CANE & 26.0 & 15.9 & 1.6 & 24.1 \\
COMA & 23.3 & 10.5 & 0.5 & 29.0 \\
GELA & 29.3 & 10.1 & 0.4 & 23.7 \\
ITTI north & 23.5 & 8.7 & 1.3 & 22.6 \\
ITTI south & 21.8 & 8.9 & 0.5 & 38.6 \\
KOTY & 41.7 & 12.6 & 2.9 & 14.5 \\
NARB center & 12.9 & 8.4 & 3.5 & 21.8 \\
NARB north & 19.5 & 12.3 & 1.0 & 11.1 \\
NARB south & 10.5 & 5.1 & 3.9 & 19.3 \\
THAU north & 16.7 & 12.5 & 1.5 & 20.7 \\
THAU south & 20.0 & 10.0 & 4.6 & 17.3 \\
URBI & 14.5 & 9.6 & & \\
\hline
\end{tabular}


Generally, metrics values showing poor and bad ecological status were positively correlated with the pollution pressure levels estimated by the LUPLES method (Table 4). Nutrient concentration, as indicated by ammonium, nitrite, orthophosphates, silica, total $\mathrm{P}$ and total $\mathrm{N}$ were generally positively correlated with eutrophication and specific pollutant pressure levels, with $p$-values $<0.01$ (except for the total nitrogen and eutrophication pressure level, with a $p$-value of 0.084 ). Dissolved oxygen concentration positively correlated both with the pressures of eutrophication and specific pollutants, with Spearman values higher than 0.29 and 0.23 , respectively ( $p$-value $<0.01$ ), whereas it correlated negatively with the organic enrichment pressure level (Spearman $-0.31, p$-value $<0.01$ ). The acidification pressure level also significantly correlated with some of these metrics, probably due to covariation, as this pressure was estimated to be low in all the studied sites. The chl- $a$ concentration was positively correlated with both eutrophication and organic pressures.

Table 4. Correlation and linear regression of the physical and chemical indicators and biological quality elements with each of the pressure types defined (EUTR: eutrophication, ORG: organic enrichment, ACID: acidification, POLL: presence of toxic pollutants). Only statistically significant correlations and regressions with $p$-value $<0.05$ are reported here. $n=$ number of corresponding metrics data used for the analysis.

\begin{tabular}{|c|c|c|c|c|c|c|c|c|}
\hline Metric & Pressure & n & Spearman & $p$-Value & Linear Regression & $\mathbf{R}^{2}$ & F & $p$-Value \\
\hline Ammonium & EUTR & 555 & 0.349 & $<0.001$ & $y=0.19 x+0.01$ & 0.193 & 14.212 & $<0.001$ \\
\hline$\left(\mu \mathrm{mol} \mathrm{N}-\mathrm{NH}_{4}{ }^{+} \mathrm{L}^{-1}\right)$ & POLL & 555 & 0.345 & $<0.001$ & $y=0.18 x+0.01$ & 0.189 & 8.959 & 0.003 \\
\hline \multirow{4}{*}{$\begin{array}{l}\text { Dissolved Oxygen } \\
\quad\left(\mu \mathrm{mol} \mathrm{O} \mathrm{L}^{-1}\right)\end{array}$} & EUTR & 756 & 0.293 & $<0.001$ & $y=9.43 x+123.61$ & 0.089 & 73.842 & $<0.001$ \\
\hline & ORG & 756 & -0.309 & $<0.001$ & $y=-11.73 x+422.20$ & 0.031 & 24.266 & $<0.001$ \\
\hline & ACID & 756 & -0.427 & $<0.001$ & $y=-33.16 x+392.91$ & 0.144 & 126.851 & $<0.001$ \\
\hline & POLL & 756 & 0.231 & $<0.001$ & $y=8.06 x+136.93$ & 0.054 & 43.271 & $<0.001$ \\
\hline \multirow{2}{*}{$\begin{array}{c}\text { Nitrite } \\
\left(\mu \mathrm{mol} N-\mathrm{NO}_{2}-\mathrm{L}^{-1}\right)\end{array}$} & EUTR & 702 & 0.196 & $<0.001$ & $y=0.03 x+0.02$ & 0.013 & 9.515 & 0.002 \\
\hline & POLL & 702 & 0.251 & $<0.001$ & $y=0.02 x+0.14$ & 0.007 & 5.125 & 0.024 \\
\hline \multirow{3}{*}{$\begin{array}{c}\text { Orthophosphate } \\
\left(\mu \mathrm{mol} \mathrm{P}-\mathrm{PO}_{4}^{3-} \mathrm{L}^{-1}\right)\end{array}$} & EUTR & 575 & 0.519 & $<0.001$ & $y=0.16 x+0.01$ & 0.188 & 22.812 & $<0.001$ \\
\hline & ACID & 575 & -0.361 & $<0.001$ & $y=-1.09 x+5.62$ & 0.058 & 32.850 & $<0.001$ \\
\hline & POLL & 575 & 0.485 & $<0.001$ & $y=0.15 x+0.01$ & 0.180 & 18.363 & $<0.001$ \\
\hline \multirow{4}{*}{$\begin{array}{c}\text { Silica } \\
\left(\mu \mathrm{mol} \mathrm{Si} \mathrm{L}{ }^{-1}\right)\end{array}$} & EUTR & 240 & 0.408 & $<0.001$ & $y=3.41 x+0.01$ & 0.408 & 23.621 & $<0.001$ \\
\hline & ORG & 240 & 0.576 & $<0.001$ & $y=7.33 x+0.01$ & 0.455 & 66.200 & $<0.001$ \\
\hline & ACID & 240 & 0.269 & $<0.001$ & $y=23.73 x+13.14$ & 0.174 & 49.951 & $<0.001$ \\
\hline & POLL & 240 & 0.554 & $<0.001$ & $y=3.35 x+0.01$ & 0.431 & 40.578 & $<0.001$ \\
\hline \multirow{3}{*}{$\begin{array}{c}\text { Total N } \\
\left(\mu \mathrm{mol} \mathrm{N} \mathrm{L}{ }^{-1}\right)\end{array}$} & ORG & 169 & 0.328 & $<0.001$ & $y=20.29 x+0.01$ & 0.438 & 57.900 & $<0.001$ \\
\hline & ACID & 169 & 0.345 & $<0.001$ & $y=106.94 x+72.86$ & 0.059 & 10.202 & 0.002 \\
\hline & POLL & 169 & 0.490 & $<0.001$ & $y=7.65 x+0.01$ & 0.407 & 2.728 & 0.050 \\
\hline \multirow{3}{*}{$\begin{array}{c}\text { Total P } \\
\left(\mu \mathrm{mol} \mathrm{P} \mathrm{L}{ }^{-1}\right)\end{array}$} & EUTR & 452 & 0.591 & $<0.001$ & $y=0.41 x+0.01$ & 0.190 & 27.814 & $<0.001$ \\
\hline & ACID & 452 & -0.364 & $<0.001$ & $y=-2.70 x+13.76$ & 0.054 & 25.519 & $<0.001$ \\
\hline & POLL & 452 & 0.560 & $<0.001$ & $y=0.38 x+0.01$ & 0.181 & 22.425 & $<0.001$ \\
\hline \multirow{2}{*}{$\begin{array}{c}\text { Chl-a } \\
\left(\mu \mathrm{g} \mathrm{L}^{-1}\right)\end{array}$} & EUTR & 440 & 0.206 & $<0.001$ & $y=0.62 x+0.01$ & 0.245 & 106.638 & $<0.001$ \\
\hline & ORG & 440 & 0.256 & $<0.001$ & $y=1.01 x+0.01$ & 0.204 & 40.635 & $<0.001$ \\
\hline \multirow{4}{*}{$\begin{array}{l}\text { Benthic inverteb. } \\
\text { (EQR) }\end{array}$} & EUTR & 13 & -0.776 & 0.002 & $y=-0.01 x+0.71$ & 0.676 & 22.974 & 0.001 \\
\hline & ORG & 13 & -0.783 & 0.002 & $y=-0.04 x+0.95$ & 0.685 & 23.942 & $<0.001$ \\
\hline & ACID & 13 & -0.708 & 0.007 & $y=-0.33 x+1.73$ & 0.823 & 51.187 & $<0.001$ \\
\hline & POLL & 13 & -0.776 & 0.002 & $y=-0.01 x+0.77$ & 0.683 & 23.705 & $<0.001$ \\
\hline
\end{tabular}

The benthic invertebrate index values, in EQR, significantly correlated with all four pollution pressure types, responding negatively to increases in each of the pollution pressure levels (Table 4). Macrophyte coverage-also as normalized data in EQR, joining the different metrics established per member state-showed a negative trend with increasing levels of pollution pressures, though these trends were not statistically significant.

Apart from the correlation, linear regression analyses were carried out to explore the response of each metric value to the pressures identified. Although linear regressions were significant, ( $p$-values $<0.05)$, a small amount of variance was explained in several cases, which could be due to the nature of the data. Each pressure level assigned in the study sites was correlated with all the available values of each metric. Therefore, for each 
$x$ value (pressure level) the results showed a vertical distribution of points through the $\mathrm{X}$-axis corresponding to the individual data for each associated sampling site at different dates, as found in the European and River Basin Authorities databases.

\subsection{Eutrophication Pressure}

The estimated eutrophication pressure level was significantly correlated with most of the metrics studied, in accordance with the expected trend. Positive correlations were found with several nutrient metrics, such as ammonium (Figure 5a), nitrite, orthophosphate or silica concentrations ( $p$-value $<0.001)$. A strong positive correlation was found with dissolved oxygen, as a measure of the increased photosynthetic activity, linked to increased trophic levels (Figure $5 b$ ). Chl- $a$ concentration was also significantly correlated with the eutrophication pressure (Figure 5c). Finally, even with a low number of samples (n), a negative correlation was found for the benthic invertebrates EQR, demonstrating the negative response of this ecological quality indicator to eutrophication (Figure $5 \mathrm{~d}$ ). In line with the correlations, the linear regressions were also significant, although, as previously mentioned, with a relatively low explained variance in most cases.

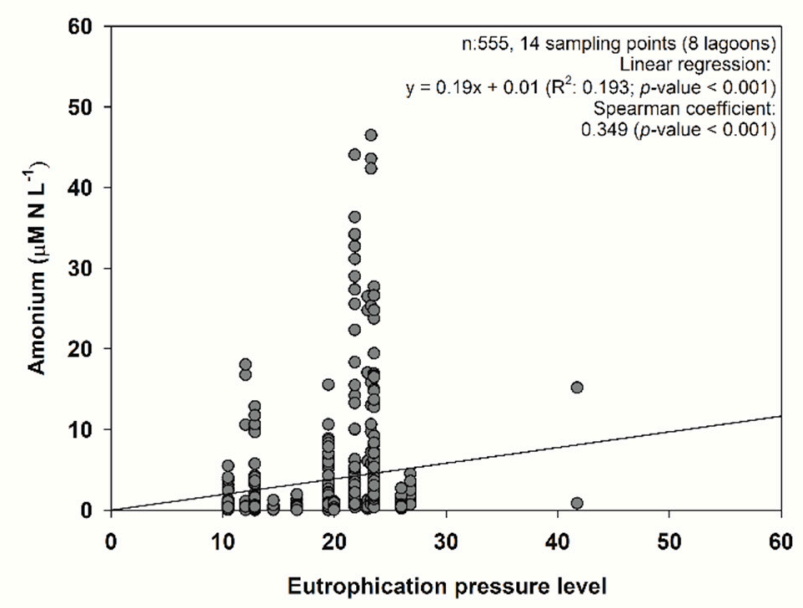

(a)

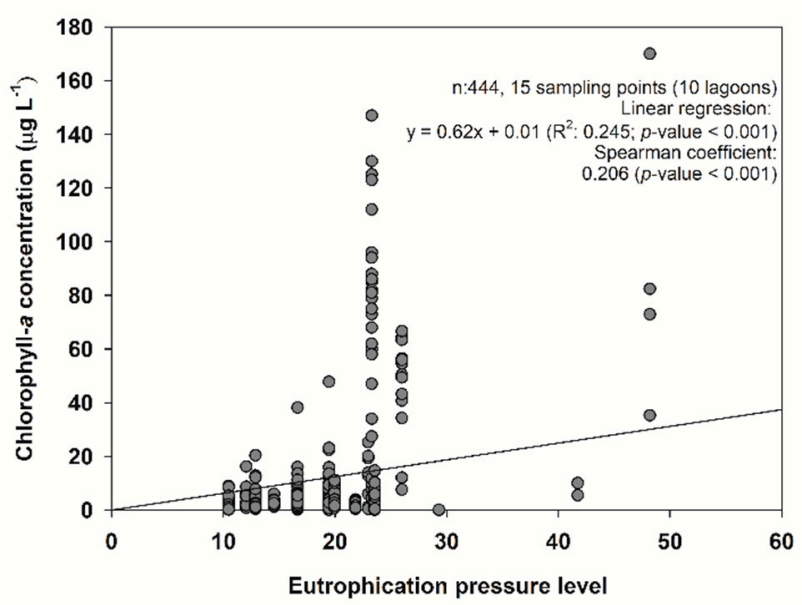

(c)

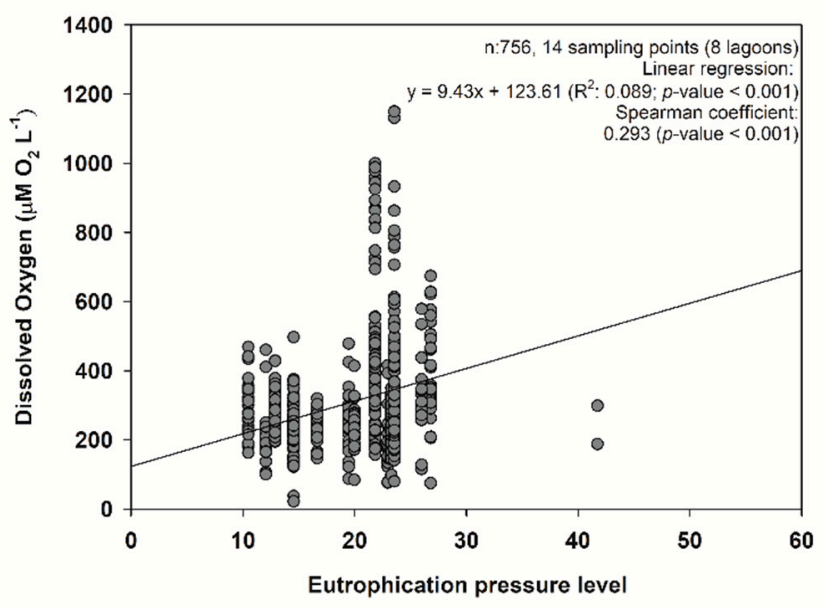

(b)

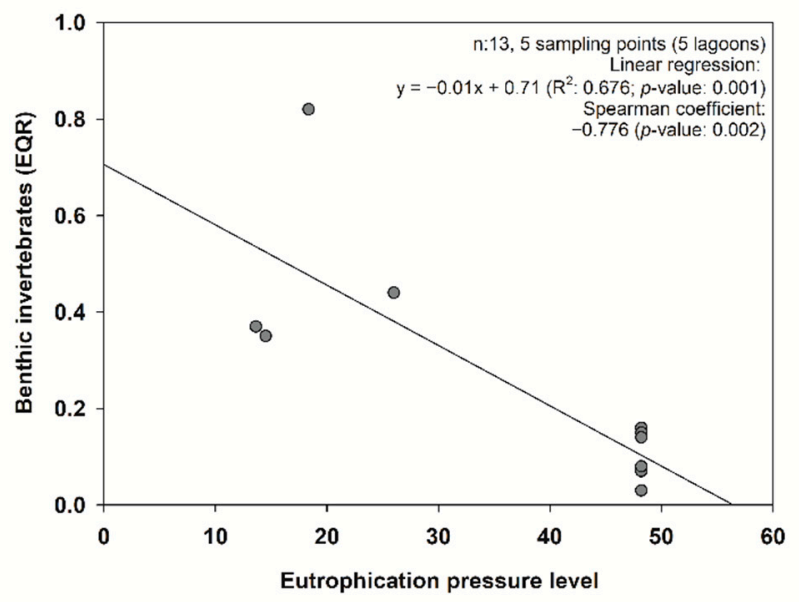

(d)

Figure 5. Relationship between the eutrophication pressure level and (a) ammonium concentration, (b) dissolved oxygen concentration, (c) chl- $a$ concentration, and (d) benthic invertebrate index, as EQR. Spearman coefficient (with the significance of the correlation), as well as linear regression (with the $\mathrm{R}^{2}$ and significance of the regression model) are shown. 


\subsection{Organic Enrichment Pressure}

Chl- $a$ concentration increased in parallel to increases in the organic enrichment pressure levels, with a significant correlation $(p$-value $<0.001)$ and linear regression $(p$-value of the regression $<0.001$ ) (Figure 6a), whereas dissolved oxygen was concentration negatively correlated with the organic enrichment pressure level as a consequence of the increased respiratory activity to this type of pressure (Figure $6 \mathrm{~b}$ ). As for the other estimated pollution pressures, the response of the benthic invertebrate indices, normalized to EQR, to the organic enrichment, was found to be significantly negative, both in the correlation analysis and the linear regression model (Table 4$)$, despite the relatively small sample size $(n=13)$.

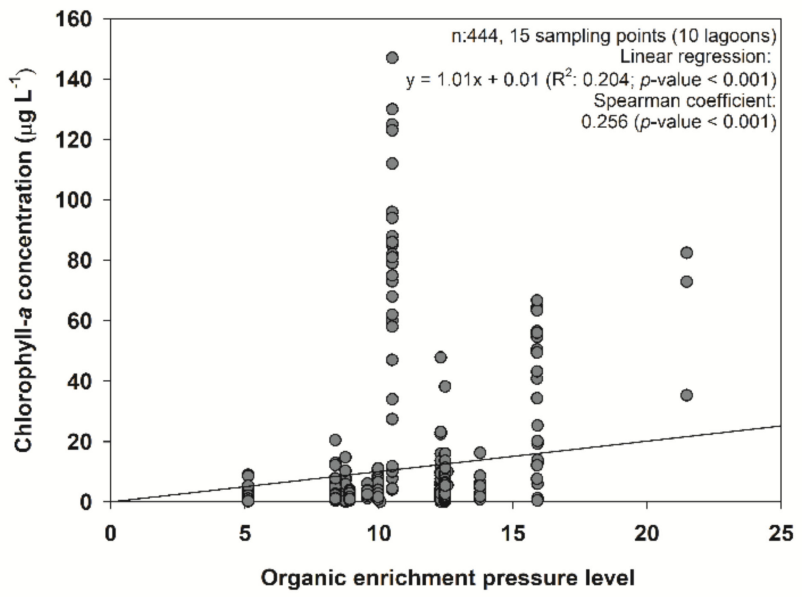

(a)

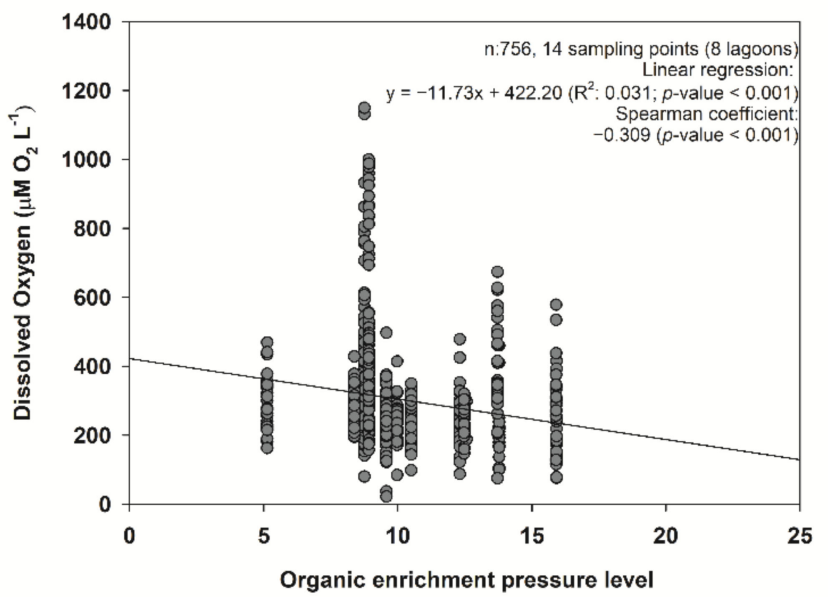

(b)

Figure 6. Relationship between organic enrichment pressure level with (a) Chl-a concentration, and (b) dissolved oxygen. Spearman coefficient (with the significance of the correlation), as well as linear regression (with the $\mathrm{R}^{2}$ and significance of the regression model) are shown.

\subsection{Specific Pollutants Pressure}

Specific pollutant pressure was significantly correlated with some nutrient concentrations, such as ammonium, nitrite, orthophosphate, silicate, total P or total $\mathrm{N}(p$-value $<0.001)$. In all these cases, linear regressions with a positive slope were also found to be significant, except for the total N (Table 4). There was also a significant positive correlation and regression for the specific pollutants pressure level with the dissolved oxygen concentration (Figure 7a). On the contrary, a significant negative correlation and regression of the specific pollutants pressure level was found with the benthic invertebrates EQR (Figure 7b), as shown for the other pollution pressures assessed.

\subsection{Hydrological and Morphological Pressures}

Table 5 shows the statistics for the hydrological and morphological pressures correlation with the ecological status metrics, based on macrophytes as biological quality element (BQE). The morphological pressures level, estimated by the LUPLES method, correlated significantly with the percentage of emerged macrophytes (helophytes) coverage, which dropped as the pressure value increased ( $p$-value $<0.001$ for the correlation and linear regression analysis) (Figure 8a). Meanwhile, the level of hydrological pressures was significantly negatively correlated with the percentage of submerged macrophyte (hydrophytes) coverage ( $p$-value $<0.001$ for the correlation and linear regression analysis) (Figure $8 b$ ), which also decreased as the hydrological pressure level increased. 


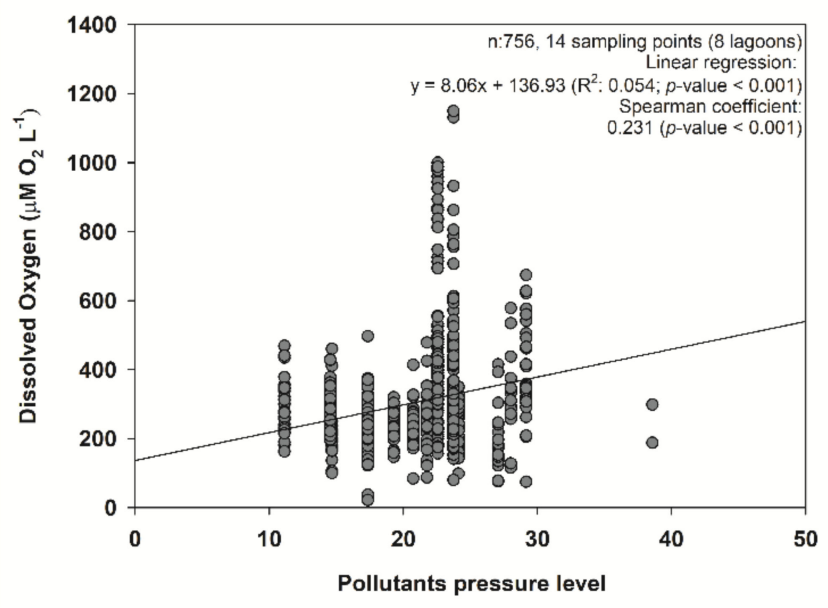

(a)

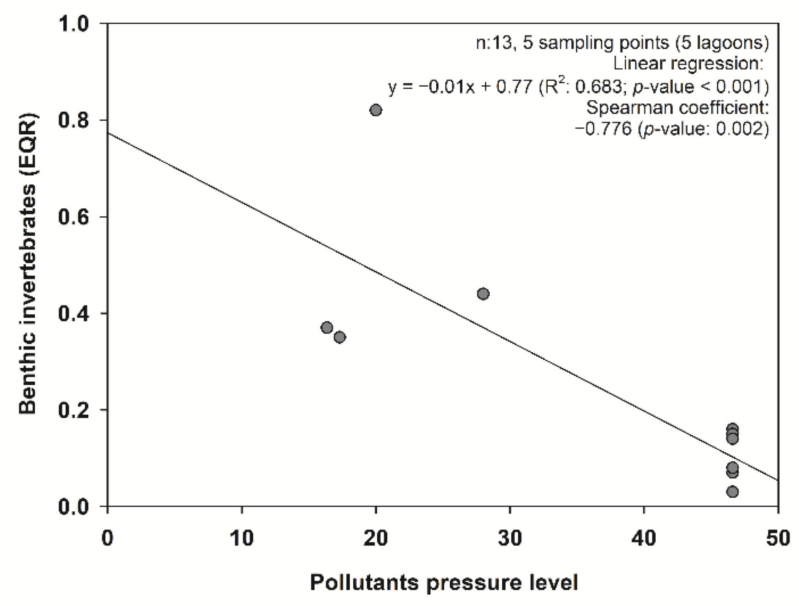

(b)

Figure 7. Relationship between specific pollutants pressure level with (a) dissolved oxygen concentration, and (b) benthic invertebrate index, as EQR. Spearman coefficient (with Table 2 and significance of the regression model) are shown.

Table 5. Correlations and linear regressions of the macrophytes metrics with the hydro-morphological pressure levels (HYDR: hydrological pressures, MORP: morphological pressures).

\begin{tabular}{ccccccccc}
\hline Metric & Pressure & $\mathbf{n}$ & Pearson & $p$-Value & Linear Regression & $\mathbf{R}^{2}$ & F & $p$-Value \\
\hline Emerged macrophytes coverage (\%) & MORP & 47 & -0.502 & $<0.001$ & $\mathrm{y}=-0.77 \mathrm{x}+78.52$ & 0.252 & 15.191 & $<0.001$ \\
\hline Submerged macrophytes coverage (\%) & HYDR & 38 & -0.697 & $<0.001$ & $\mathrm{y}=-1.58 \mathrm{x}+70.11$ & 0.487 & 33.954 & $<0.001$ \\
\hline
\end{tabular}

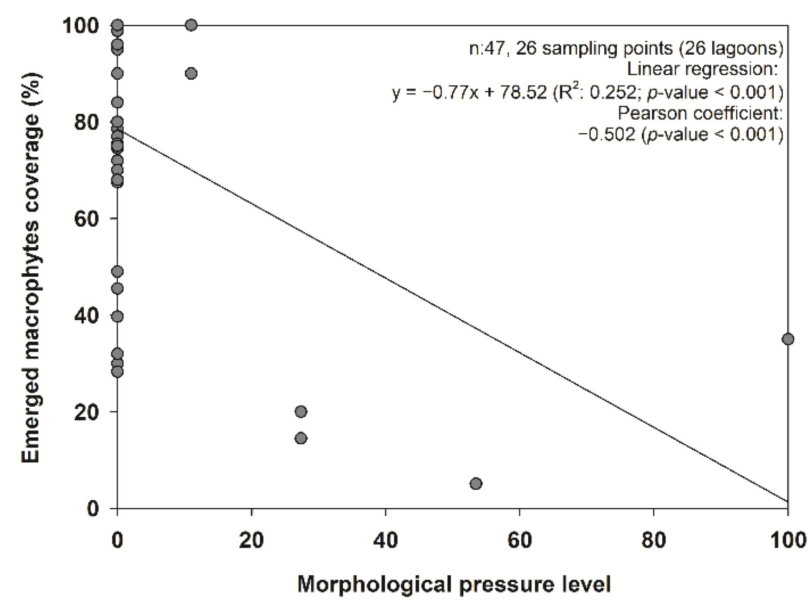

(a)

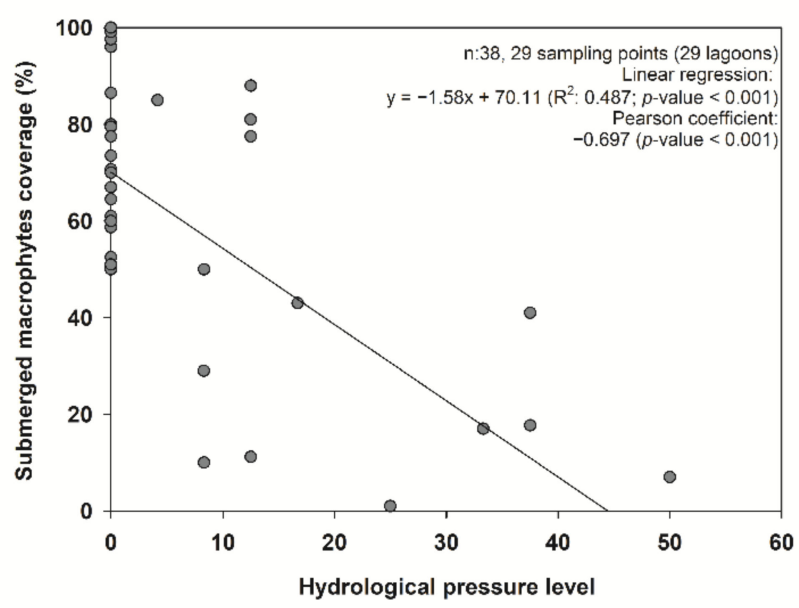

(b)

Figure 8. Relationship between (a) morphological pressure level with helophyte coverage and (b) hydrological pressure level with hydrophyte coverage. Pearson coefficient (with the significance of the correlation), as well as linear regression (with the $\mathrm{R}^{2}$ and significance of the regression model) are shown.

\section{Discussion}

The methodology proposed here, the LUPLES method, uses GIS techniques and the mapping of waterbodies and land uses in their catchment area, as well as the assessment of direct and indirect influences on their hydrology and morphology, to quantify pressures on lentic ecosystems. The method then presents a forecast of its possible ecological status. 
In line with the method developed in this study, land uses have been demonstrated to have direct influences on changes in the water quality [54], as well as in the responses of biotic elements [18]. Therefore, as we have demonstrated, they can be used as a proxy to define pressures that are capable of inducing changes in the ecological characteristics of lentic ecosystems. The alterations to hydrological and morphological features, both in the catchment area and the waterbody itself, can also be considered as a source of pressures, as they are capable of modifying the ecological features of the waterbodies [19]. The response of aquatic ecosystems to the defined pressures were reflected in the impacts on the physical, chemical, biological and hydro-morphological indicators, as those established by the WFD guidelines [33].

For pollution-related pressures, the LUPLES method considers the relative influence of each land use according to its relative surface coverage of the whole catchment, and its relative importance for such pressure. The application of this methodology for evaluating land use in the whole catchment and not just in the near-waterbody, is supported by the strong relationship existing between the activities and uses in the entire catchment and water quality [10]. The LUPLES method considers the main implications that different land uses (e.g., irrigated and rain-fed agriculture, livestock, or urban uses) have on eutrophication [44-46], organic enrichment [47], acidification [48,49] and pollutants [50-52].

In the studied sites, the eutrophication pressure level was mainly determined by agricultural land use, with a higher weighting for irrigated agriculture. The weight of agriculture in the global value of the method proposed was decisive considering the implications of agricultural land use in the catchment area on the water quality of the lagoons [44-46], as this consists of the main source contributing nutrients via runoff $[9,10]$. The values obtained from our method were higher in Albufera de València and, to a lesser extent, in Kotychi lagoon; the sites with a higher level of irrigated agriculture relative coverage in their catchment. These two sites, with a very high eutrophication pressure assessment, have been historically altered ([55] for Kotychi lagoon), with a permanent occurrence of cyanobacterial blooms due to nutrient enrichment ([38] for Albufera de València). Other sites with high eutrophication pressure levels, with LUPLES method values between 10 and 20, were located in highly altered catchments, with a percentage of agriculture coverage above 50 or even $75 \%$ of the total area, such as Etang de Canet, Stagno di Cábras, Valli residue del comprensorio di Comacchio, Biviere di Gela or Stagno di Corru S'Ittiri. Generally, all the studied coastal lagoons presented a eutrophication pressure level above 10, which is in agreement with the general degradation of the coastal systems [56]. The specific pollutants pressure level presented quite similar results, especially in terms of the relationship between agriculture and the use of nutrients and chemical compounds as fertilizers or pesticides [57]. For the organic enrichment pressure level, Albufera de València was the only site with a value above 20, i.e., a high pressure level. Apart from the organic matter that can originate from agriculture [38], the Albufera catchment is highly populated, with urban uses representing an important source of pressures [3]. The acidification pressure level correlated significantly with some of these metrics, however, since this pressure was estimated to be low in all the studied sites, this may be considered as a spurious correlation that is mostly due to covariation. Further refinement of the specific assessment algorithms for this type of pressure seems to be necessary in order to refine our method. Subsequent analyses, such as genetic programming, will allow us to refine the method for this type of pressure, and indeed, the rest of the pressure types in future work, with validations using additional sites and data sources [25].

Pressure levels estimated by land use in the catchment area could be translated into changes in some ecological parameters on the waterbody, which could also imply reductions in their ecological status [12]. The levels of pressures estimated by the LUPLES is coherent with the impacts measured by the ecological status indicators on the waterbodies, showing a degreasing ecological status in response to increased levels of pressures, as we have shown in our study, which validates the method developed. 
One of the ecosystem pressure responses estimated by our method, was the positive correlation between the estimated pressure levels and the concentrations of nitrogen and phosphorus. These significant correlations demonstrated the relationship that exists between land use in the catchments and the level of eutrophication pressure, as reported in previous studies [10]. Another effect of the increased pressure on the status of the waterbody was the response of metabolic activity as a measure of ecosystem functioning, especially induced by eutrophication and organic enrichment $[58,59]$. A positive correlation between the eutrophication pressure level and the dissolved oxygen concentration (DO) was found, in accordance with the expected response of the ecosystem by the proliferation of photosynthetic organisms [60]. Contrarily, a negative correlation of DO with the organic enrichment pressure level was found, as the increases in organic matter availability can promote exacerbated growth of heterotrophic organisms, thus enhancing oxygen-consuming organic matter degradative metabolism, namely, respiration [61].

The impacts on biological communities also showed clear responses to the pressure levels estimated by the LUPLES method. Sites with high pressure levels where those with poorer values of indicators of bad ecological status (such as chl- $a$ concentration), also showing lower values of indicators of good ecological status (such as the benthic invertebrate EQR), which indicates the clear relationship between the pressures quantified by our method and their associated impacts on the biological communities. The response of the biological indicators to the pressures assessed by the LUPLES method was studied by the BQE, defined in the WFD, which is already intercalibrated and used at the European level $[62,63]$, using the normalized values (EQR) to allow the comparison of the assessed impact, regardless the metric used.

Eutrophication pressure levels determined by the LUPLES method correlated significantly with the chl- $a$ concentration, defined as one of the main metrics for the BQEphytoplankton, used for ecological quality assessment $[13,64]$. Organic enrichment pressures also corelated significantly with the chl- $a$ concentration, which suggested a proper estimation of the defined pressure, as the decomposition of organic matter provides inorganic nutrients which enhances phytoplankton growth [65].

The pollution pressures defined by the LUPLES also showed negative significant effects on benthic invertebrate assemblages. The structure and composition of the communities of these organisms have been widely studied as indicators of the ecological status of waterbodies [66,67], representing good indicators of the effects of eutrophication on the ecological quality of the waterbody [14], organic enrichment [68], toxic pollution [16], and acidification [15]. In our case, the results for benthic invertebrates also validated our hypothesis, with a significant negative response of the four water quality pressure types to the normalized data, based on benthic invertebrate indicators.

Contrarily to phytoplankton and benthic invertebrates, no statistically significant relationship between pollution pressure level and macrophytes was found, although a negative trend was apparent. We would expect a reduction in macrophyte coverage with increases in the eutrophication pressure level [69], although there are more sensitive or more tolerant taxa already defined as indicators by the WFD [70]. Depending on the nature of the macrophyte indices, based on abundance, richness, or a combination of both, they could be more or less sensitive to the assessed pollution pressures.

Macrophytes, however, are also used as indicators of the impacts caused by hydrological and morphological pressures, and their coverage is used as a metric of the ecological status for the BQE "other aquatic flora" [43]. Considering the relevance of the hydro-morphology of the waterbody for the status of macrophyte communities [19], the identification of hydrological and morphological pressures is key for ecological status assessments [63]. This is even more important in Mediterranean waterbodies due to the higher levels of hydrological stress [43]. The LUPLES method proposes the assessment of these two types of pressures separately, by estimating the direct alterations on the water fluxes in the catchment, as well as by alterations of the waterbody shoreline and banks. Hydrological alterations, assessed by the LUPLES method, were correlated negatively 
with the percentage of submerged macrophytes, meanwhile, morphological alterations correlated negatively with helophytes coverage.

Although our results generally showed statistically significant correlations between the pressure levels assessed by the LUPLES method and the metric values, in some cases some statistics were weak (i.e., even if $p$-values showed statistically significant relationships, the percentage of variance explained was not very high). This could be explained by several factors. First, the data were obtained from raw databases, where the values of the metrics of the different member states are stored. We assumed that they were obtained using similar or comparable methods (the so-called "intercalibrated methods" according to the WFD terminology). On the other hand, they correspond to historical series, which, for the data used, were collected between 2004-2013. The pressures assessed were estimated at a fixed time point, based on the 2012 maps, since the available information on the metrics was not so abundant as to be suitable to make correlations in different time periods. Each waterbody could have large deviations in their historic series of data, sometimes with high intra-annual variation, as naturally occurs in Mediterranean waterbodies. For the BQE macrophytes and benthic invertebrates, with almost no data for the studied lagoons in the European databases, we compiled the EQR values for the waterbodies included in the study from national reports of the River Basin Authorities from Spain and France, where we found a relatively low number of values. Still, significant trends in some of the indicators studied gave insights into the relationship between the pressure levels obtained from land uses in the catchments and the ecological status assessed by the indicators used. Data for the hydrological alterations were retrieved from a Spanish database that collects the volume of the waterbodies and the height of damming for modified waterbodies, and this allowed for the identification of correlations between the hydrological pressures and macrophyte metrics values.

The application of the LUPLES methodology demonstrated the validity of using land use map data as proxies for the estimation of pollution impacts and direct alterations on the hydro-morphology, through the estimation of the different pressures affecting waterbodies, as they responded to the impacts requested by the WFD [33]. Specifically, the six main pressure types assessed (eutrophication, organic enrichment, acidification, toxic pollutants, hydrological and morphological pressures) correlated with some of the main indicators of ecological status developed for the implementation of the WFD [32]. In addition, the pressure level was reflected in the impacts on the physical-chemical features and BQE of the waterbodies. The methodological approach described here, combined with the use of the available information and GIS techniques, can be a used not only as an effective method to estimate the pressures on lentic waterbodies, but also as a first approach to predict the ecological status of these ecosystems.

Despite the fact that ensuring the monitoring of water bodies is mandatory according to the WFD, there are many aquatic ecosystems that do not have monitoring programs, either because they are not declared as waterbodies, or because they are not under the European regulations, due to them being outside of the European Union. Faster and cheaper methods, such as that proposed here, may help to approach the assessment of the pressures as an indirect way to identify their ecological status when monitoring facilities are not available.

Currently, there are multiple sources of geographic information, which represent not only a wide basis to generate knowledge, but also to be applied in the monitoring and management of ecosystems. In this work, we worked with Digital Elevation Models (DEM) that are used for the delimitation of watersheds. These three-dimensional raster are now available at high resolution for the whole of the surface of Europe [42]. On the other hand, Corine-Land Cover (CLC) maps are widely used in many studies [23,54]. These maps-also available for the whole of Europe [29] — are updated, and may even include maps of land use changes (LULUC). GIS software allows for multiple studies to be carried out using this information through its tools. On the other hand, satellite images in viewers such as Google Earth Pro are highly useful for the assessment of morphological pressures. Applied 
science studies, such as our work, and others focused on determining and developing methodologies for use in the management and monitoring of waterbodies [27,54], can be of great importance and represent advances that improve the quality of assessments and reduce costs. This is especially useful for covering a larger number of lakes and wetlands, not just those declared as waterbodies in accordance with the WFD by the River Basin Authorities. It would be interesting to combine field and laboratory measurements, as real data on the conservation and ecological status, with applications from GIS or remote sensing, using methods such as LUPLES for estimating pressure levels, to predict the response of the ecological status of ecosystems to the variation of types and levels of different pressures.

\section{Conclusions}

In this work, a methodological approach for estimating pressures in lentic ecosystems was presented. The method developed starts by assessing the relationship that exists between types of land use in the catchment areas, and the influences of this on pollution pressures (eutrophication, organic enrichment, acidification, and pollutants). Additionally, the method also includes a direct determination of hydro-morphological pressures. The algorithms used were based on the relative area of each land use in the catchment, weighted by factors that are related to the influence of each type of land use with the level of the pressure evaluated. Hydrological and morphological pressure levels were also defined from their influence on the water exchange and alterations in the waterbody shoreline and immediate basin. The LUPLES method was statistically validated by the correlation and linear regression of the pressure values obtained by various physical-chemical parameters, and the ecological status indicators, mostly biological metrics established by the member states of the European Water Framework Directive (WFD). By using the described methodology, it was possible to assess the pressures acting on each lentic waterbody, through the use of GIS techniques and DEM and land use information that are available for free from different sources. These techniques could be used to reinforce and expand in situ ecological status assessment methods, and could also alternatively be used when conventional approaches cannot be implemented.

Supplementary Materials: The following are available online at https:/ / www.mdpi.com/2076-341 7/11/4/1633/s1, Table S1. Study sites selected for the estimation and validation of the hydrological and morphological pressures; Table S2. Data sources for the benthic invertebrates and macrophyte EQR, and emerged and submerged macrophyte metrics; Table S3. Availability of these different parameters in the studied lagoons. Sources: WATERBASE European database for the physicalchemical and chlorophyll-a parameters, and River Basin Authorities from Spain and France for the EQR values of benthic invertebrates and macrophytes.

Author Contributions: Conceptualization, A.C., D.M. and C.P.; methodology, D.M. and A.C.; software, D.M.; validation, A.C., D.M. and C.P.; formal analysis, D.M.; investigation, D.M.; resources, A.C. and C.P.; data curation, D.M.; writing-original draft preparation, D.M.; writing - review and editing, A.C.; visualization, A.C.; supervision, C.P. and A.C.; project administration, A.C.; funding acquisition, A.C. All authors have read and agreed to the published version of the manuscript.

Funding: This research was funded by the MINECO and the Agencia Estatal de Investigación of the Spanish Government through projects CLIMAWET (CGL2015-69557-R) and CLIMAWET-CONS (PID2019-104742RB-I00), respectively, both cofounded by European FEDER Funds, one way to make Europe. DM hold a FPU Predoctoral Scholarship by the Spanish Ministry of Science Innovation and Universities, grant number FPU16/01444, and benefited from a short stay grant within the FPU program.

Institutional Review Board Statement: Not applicable.

Informed Consent Statement: Not applicable.

Data Availability Statement: The data presented in this study are available on request from the corresponding author. 
Acknowledgments: The authors are indebted to the Dirección General del Agua (Spanish Government) and the European Environmental Agency for the data availability on public repositories. We would also like to thank Anis Guelmami for his help with the GIS techniques.

Conflicts of Interest: The authors declare no conflict of interest.

\section{References}

1. Verhoeven, J.T. Wetlands in Europe: Perspectives for restoration of a lost paradise. Ecol. Eng. 2014, 66, 6-9. [CrossRef]

2. Kingsford, R.T.; Basset, A.; Jackson, L. Wetlands: Conservation's poor cousins. Aquat. Conserv. 2016, 26, 892-916. [CrossRef]

3. Ruiz-Luna, A.; Berlanga-Robles, C.A. Land use, land cover changes and coastal lagoon surface reduction associated with urban growth in northwest Mexico. Landsc. Ecol. 2003, 18, 159-171. [CrossRef]

4. Galbraith, L.M.; Burns, C.W. Linking land-use, water body type and water quality in southern New Zealand. Landsc. Ecol. 2007, 22, 231-241. [CrossRef]

5. Phillips, J.D. Wetland buffers and runoff hydrology. In Wetlands: Environmental Gradients, Boundaries, and Buffers; Mulamoottil, G., Warner, B.G., McBean, E.A., Eds.; CRC Press: New York, NY, USA, 1996; pp. 207-220.

6. Verhoeven, J.T.; Arheimer, B.; Yin, C.; Hefting, M.M. Regional and global concerns over wetlands and water quality. Trends Ecol. Evol. 2006, 21, 96-103. [CrossRef]

7. Vymazal, J.; Březinová, T. The use of constructed wetlands for removal of pesticides from agricultural runoff and drainage: A review. Environ. Int. 2015, 75, 11-20. [CrossRef]

8. Camacho, A.; Picazo, A.; Rochera, C.; Peña, M.; Morant, D.; Miralles-Lorenzo, J.; Santamans, A.C.; Estruch, H.; Montoya, T.; Fayos, G.; et al. Serial use of Helosciadum nodiflorum and Typha latifolia in Mediterranean constructed wetlands to naturalize effluents of wastewater treatment plants. Water 2017, 10, 717. [CrossRef]

9. Boskidis, I.; Gikas, G.D.; Pisinaras, V.; Tsihrintzis, V.A. Spatial and temporal changes of water quality, and SWAT modeling of Vosvozis river basin, North Greece. J. Environ. Sci. Health A 2010, 45, 1421-1440. [CrossRef] [PubMed]

10. Nielsen, A.; Trolle, D.; Søndergaard, M.; Lauridsen, T.L.; Bjerring, R.; Olesen, J.E.; Jeppesen, E. Watershed land use effects on lake water quality in Denmark. Ecol. Appl. 2012, 22, 1187-1200. [CrossRef] [PubMed]

11. Moreno-Mateos, D.; Mander, Ü.; Comín, F.A.; Pedrocchi, C.; Uuemaa, E. Relationships between landscape pattern, wetland characteristics, and water quality in agricultural catchments. J. Environ. Qual. 2008, 37, 2170-2180. [CrossRef]

12. Haidary, A.; Amiri, B.J.; Adamowski, J.; Fohrer, N.; Nakane, K. Assessing the impacts of four land use types on the water quality of wetlands in Japan. Water Resour. Manag. 2013, 27, 2217-2229. [CrossRef]

13. Carvalho, L.; Poikane, S.; Solheim, A.L.; Phillips, G.; Borics, G.; Catalan, J.; De Hoyos, C.; Drakare, S.; Dudley, B.J.; Järvinen, M.; et al. Strength and uncertainty of phytoplankton metrics for assessing eutrophication impacts in lakes. Hydrobiologia 2013, 704, 127-140. [CrossRef]

14. Word, J.Q. Classification of benthic invertebrates into infaunal trophic index feeding groups. In Southern California Coastal Water Research Project Biennial Report; Southern California Coastal Water Research Project: Long Beach, CA, USA, 1980 ; pp. $103-121$.

15. McFarland, B.; Carse, F.; Sandin, L. Littoral macroinvertebrates as indicators of lake acidification within the UK. Aquat. Conserv. 2010, 20, 105-116. [CrossRef]

16. Archaimbault, V.; Usseglio-Polatera, P.; Garric, J.; Wasson, J.G.; Babut, M. Assessing pollution of toxic sediment in streams using bio- ecological traits of benthic macroinvertebrates. Freshw. Biol. 2010, 55, 1430-1446. [CrossRef]

17. European Commission. Directive 2013/39/EC of the European Parliament and the Council of 12 August 2013 as Regards the Priority Substances in the Field of Water Policy. Official Journal of the European Communities, L226/1. Luxembourg. 2013. Available online: https:/ / eur-lex.europa.eu/LexUriServ/LexUriServ.do?uri=OJ:L:2013:226:0001:0017:EN:PDF (accessed on 15 October 2019).

18. Dodson, S.I.; Lillie, R.A.; Will-Wolf, S. Land use, water chemistry, aquatic vegetation, and zooplankton community structure of shallow lakes. Ecol. Appl. 2005, 15, 1191-1198. [CrossRef]

19. Camacho, A.; Peinado, R.; Santamans, A.C.; Picazo, A. Functional ecological patterns and the effect of anthropogenic disturbances on a recently restored Mediterranean coastal lagoon. Needs for a sustainable restoration. Estuar. Coast. Shelf Sci. 2012, 114, 105-117. [CrossRef]

20. Camacho, A.; Murueta, N.; Blasco, E.; Santamans, A.C.; Picazo, A. Hydrology-driven macrophyte dynamics determines the ecological functioning of a model Mediterranean temporary lake. Hydrobiologia 2016, 774, 93-107. [CrossRef]

21. Ferriol, C.; Miracle, M.R.; Vicente, E. Effects of nutrient addition, recovery thereafter and the role of macrophytes in nutrient dynamics of a Mediterranean shallow lake: A mesocosm experiment. Mar. Freshw. Res. 2017, 68, 506-518. [CrossRef]

22. MacKay, H.; Finlayson, C.M.; Fernandez-Prieto, D.; Davidson, N.; Pritchard, D.; Rebelo, L.M. The role of Earth Observation (EO) technologies in supporting implementation of the Ramsar Convention on Wetlands. J. Environ. Manag. 2009, 90, $2234-2242$. [CrossRef]

23. Jones, K.; Lanthier, Y.; van der Voet, P.; van Valkengoed, E.; Taylor, D.; Fernández-Prieto, D. Monitoring and assessment of wetlands using Earth Observation: The GlobWetland project. J. Environ. Manag. 2009, 90, 2154-2169. [CrossRef]

24. Perennou, C.; Guelmami, A.; Paganini, M.; Philipson, P.; Poulin, B.; Strauch, A.; Tottrup, C.; Truckenbrodt, J.; Geijzendorffer, I.R. Chapter Six-Mapping Mediterranean wetlands with remote sensing: A good-looking map is not always a good map. In 
Advances in Ecological Research; Bohan, D.A., Dumbrell, A.J., Woodward, G., Jackson, M., Eds.; Academic Press: Cambridge, MA, USA, 2018; Volume 58, pp. 243-277. [CrossRef]

25. Doña, C.; Chang, N.; Caselles, V.; Sánchez, J.M.; Pérez-Planells, L.; Bisquert, M.; García-Santos, V.; Imen, S.; Camacho, A. Monitoring hydrological patterns of temporary lakes using remote sensing and machine learning models: Case study of a Mancha Húmeda Biosphere Reserve in central Spain. Remote Sens. 2016, 8, 618. [CrossRef]

26. Doña, C.; Sanchez, J.M.; Caselles, V.; Dominguez, J.A.; Camacho, A. Empirical relationships for monitoring water quality of lakes and reservoirs through multispectral images. IEEE J. Sel. Top. Appl. Earth Obs. Remote Sens. 2014, 7, 1632-1641. [CrossRef]

27. Doña, C.; Chang, N.B.; Caselles, V.; Sánchez, J.M.; Camacho, A.; Delegido, J.; Vannah, B.W. Integrated satellite data fusion and mining for monitoring lake water quality status of the Albufera de Valencia in Spain. J. Environ. Manag. 2015, 151, 416-426. [CrossRef] [PubMed]

28. Büttner, G.; Feranec, J.; Jaffrain, G.; Mari, L.; Maucha, G.; Soukup, T. The CORINE land cover 2000 project. EARSeL eProceedings 2004, 3, 331-346.

29. European Environmental Agency. CORINE Land Cover; European Environmental Agency: Copenhagen, Denmark, 2019. Available online: https: / / land.copernicus.eu/pan-european/corine-land-cover (accessed on 15 October 2019).

30. Satellite-Based Wetland Observation Service. Available online: https:/ / www.swos-service.eu/ (accessed on 15 December 2020).

31. European Commission. Directive 2000/60/EC of the European Parliament and the Council of 23 October 2000 Establishing a Framework for Community Action in the Field of Water Policy. Official Journal of the European Communities, L327/1. Luxembourg. 2000. Available online: https:/ / eur-lex.europa.eu/legal-content/EN/TXT/?uri=CELEX\%3A32000L0060 (accessed on 15 October 2019).

32. Allan, I.J.; Vrana, B.; Greenwood, R.; Mills, G.A.; Roig, B.; Gonzalez, C. A “toolbox" for biological and chemical monitoring requirements for the European Union's Water Framework Directive. Talanta 2006, 69, 302-322. [CrossRef] [PubMed]

33. Poikane, S.; Zampoukas, N.; Borja, A.; Davies, S.P.; van de Bund, W.; Birk, S. Intercalibration of aquatic ecological assessment methods in the European Union: Lessons learned and way forward. Environ. Sci. Policy 2014, 44, 237-246. [CrossRef]

34. DG Environment. Reporting under Article 17 of the Habitats Directive: Explanatory Notes and Guidelines for the Period 2013-2018. Brussels, Belgium, 2017. Available online: https:/ / circabc.europa.eu/sd/a/d0eb5cef-a216-4cad-8e77-6e4839a5471d/ Reporting\%20guidelines\%20Article\%2017\%20final\%20May\%202017.pdf (accessed on 15 December 2020).

35. European Environmental Agency. Waterbase-Water Quality; European Environmental Agency: Copenhagen, Denmark, 2019. Available online: https:/ / www.eea.europa.eu/data-and-maps/data/waterbase-water-quality-2 (accessed on 15 October 2019).

36. Ministerio Para la Transición Ecológica. Protocolo de Laboratorio y Cálculo de Métricas de otro tipo de Flora Acuática (macrófitos) en Lagos (OFALAM-2013). Ministerio Para la Transición Ecológica: Madrid, Spain, 2013. Available online: https://www.miteco.gob.es/es/agua/temas/estado-y-calidad-de-las-aguas/OFALAM-2013\%20v1_Laboratorio\%20y\%20 calculo_metricas_Otra\%20flora\%20acu\%C3\%A1tica\%20Macrofitos_Lagos_(30_01_2014_)_tcm30-175296.pdf (accessed on 15 December 2020).

37. Ministerio para la Transición Ecológica. DATAGUA-2008: Inventario de Presiones en Aguas Superficiales; Ministerio Para la Transición Ecológica: Madrid, Spain, 2019. Available online: https:/ / www.MITECO.gob.es/es/cartografia-y-sig/ide/descargas/agua/ datagua-2008.aspx (accessed on 15 January 2019).

38. Sòria-Perpinyà, X.; Vicente, E.; Urrego, P.; Pereira-Sandoval, M.; Ruíz-Verdú, A.; Delegido, J.; Soria, J.M.; Moreno, J. Remote sensing of cyanobacterial blooms in a hypertrophic lagoon (Albufera of València, Eastern Iberian Peninsula) using multitemporal Sentinel-2 images. Sci. Total Environ. 2020, 698, 134305. [CrossRef]

39. Erostate, M.; Huneau, F.; Garel, E.; Lehmann, M.F.; Kuhn, T.; Aquilina, L.; Vergnaud-Ayraud, V.; Labasque, T.; Santonia, S.; Robert, S.; et al. Delayed nitrate dispersion within a coastal aquifer provides constraints on land-use evolution and nitrate contamination in the past. Sci. Total Environ. 2018, 644, 928-940. [CrossRef] [PubMed]

40. Bec, B.; Collos, Y.; Souchu, P.; Vaquer, A.; Lautier, J.; Fiandrino, A.; Benau, L.; Orsoni, V.; Laugier, T. Distribution of picophytoplankton and nanophytoplankton along an anthropogenic eutrophication gradient in French Mediterranean coastal lagoons. Aquat. Microb. Ecol. 2011, 63, 29-45. [CrossRef]

41. Manno, E.; Vassallo, M.; Varrica, D.; Dongarrà, G.; Hauser, S. Hydrogeochemistry and water balance in the coastal wetland area of "Biviere di Gela," Sicily, Italy. Water Air Soil Pollut. 2007, 178, 179-193. [CrossRef]

42. European Environmental Agency. Copernicus Land Monitoring Service-EU-DEM Digital Elevated Models; European Environmental Agency: Copenhagen, Denmark, 2019. Available online: https://land.copernicus.eu/imagery-in-situ/eu-dem/eu-dem-v1-0 -and-derived-products/view (accessed on 15 October 2019).

43. Centro de Estudios y Experimentación de Obras Públicas. Selección de métricas para la evaluación del estado ecológico de las masas de agua de la categoría "lagos" basadas en el elemento de calidad "composición y abundancia de otro tipo de flora acuática". In En Aplicación de la Directiva Marco del Agua; Centro de Estudios y Experimentación de Obras Públicas: Madrid, Spain, 2010.

44. Tilman, D. Global environmental impacts of agricultural expansion: The need for sustainable and efficient practices. Proc. Natl. Acad. Sci. USA 1999, 96, 5995-6000. [CrossRef]

45. Withers, P.J.; Neal, C.; Jarvie, H.P.; Doody, D.G. Agriculture and eutrophication: Where do we go from here? Sustainability 2014, 6, 5853-5875. [CrossRef] 
46. Álvarez, X.; Valero, E.; Santos, R.M.; Varandas, S.G.P.; Fernandes, L.S.; Pacheco, F.A.L. Anthropogenic nutrients and eutrophication in multiple land use watersheds: Best management practices and policies for the protection of water resources. Land Use Policy 2017, 69, 1-11. [CrossRef]

47. Aitkenhead-Peterson, J.A.; Steele, M.K.; Nahar, N.; Santhy, K. Dissolved organic carbon and nitrogen in urban and rural watersheds of south-central Texas: Land use and land management influences. J. Environ. Earth Sci. 2009, 96, 119-129. [CrossRef]

48. Blodau, C. A review of acidity generation and consumption in acidic coal mine lakes and their watersheds. Sci. Total Environ. 2006, 369, 307-332. [CrossRef] [PubMed]

49. Das, B.; Nordin, R.; Mazumder, A. Watershed land use as a determinant of metal concentrations in freshwater systems. Environ. Geochem. Health 2009, 31, 595-607. [CrossRef] [PubMed]

50. Sonzogni, W.C.; Chesters, G.; Coote, D.R.; Jeffs, D.N.; Konrad, J.C.; Ostry, R.C.; Robinson, J.B. Pollution from land runoff. Environ. Sci. Technol. 1980, 14, 148-153. [CrossRef]

51. Cooper, C.M. Biological effects of agriculturally derived surface water pollutants on aquatic systems-A review. J. Environ. Qual. 1993, 22, 402-408. [CrossRef]

52. Moss, B. Water pollution by agriculture. Phil. Trans. Royal Soc. Lond. B 2008, 363, 659-666. [CrossRef] [PubMed]

53. MITECO. Spanish System for the Assessment of the Ecological Status of Lake Water Bodies: Pressure Level Estimation and Response of Metrics; Ministerio para la Transición Ecológica: Madrid, Spain, 2019.

54. Flo, E.; Garcés, E.; Camp, J. Land Uses Simplified Index (LUSI): Determining land pressures and their link with coastal eutrophication. Front. Mar. Sci. 2019, 6, 18. [CrossRef]

55. Kalivas, D.P.; Kollias, V.J.; Karantounias, G. A GIS for the assessment of the spatio-temporal changes of the Kotychi Lagoon, Western Peloponnese, Greece. Water Resour. Manag. 2003, 17, 19-36. [CrossRef]

56. Smith, V.H. Eutrophication of freshwater and coastal marine ecosystems a global problem. Environ. Sci. Pollut. Res. 2003, 10, 126-139. [CrossRef] [PubMed]

57. Sun, B.; Zhang, L.; Yang, L.; Zhang, F.; Norse, D.; Zhu, Z. Agricultural non-point source pollution in China: Causes and mitigation measures. AMBIO 2012, 41, 370-379. [CrossRef] [PubMed]

58. Kremer, J.N.; Wainright, S.C. Ecosystem production and respiration in response to eutrophication in shallow temperate estuaries. Mar. Ecol. Prog. Ser. 1996, 141, 263-274. [CrossRef]

59. Morant, D.; Picazo, A.; Rochera, C.; Santamans, A.C.; Miralles-Lorenzo, J.; Camacho-Santamans, A.; Ibañez, C.; Martínez-Eixarch, M.; Camacho, A. Carbon metabolic rates and GHG emissions in different wetland types of the Ebro Delta. PLoS ONE 2020, 15, e0231713. [CrossRef]

60. Smith, V.H. Using primary productivity as an index of coastal eutrophication: The units of measurement matter. J. Plankton Res. 2007, 29, 1-6. [CrossRef]

61. Maynard, J.J.; Dahlgren, R.A.; O'Geen, A.T. Autochthonous and allochthonous carbon cycling in a eutrophic flow-through wetland. Wetlands 2014, 34, 285-296. [CrossRef]

62. European Commission. Commission Decision (EU) 2018/229 of 12 February 2018 Establishing, Pursuant to Directive 2000/60/EC of the European Parliament and of the Council, the Values of the Member State Monitoring System Classifications as a Result of the Intercalibration Exercise and Repealing Commission Decision 2013/480/EU. Official Journal of the European Communities, L47: 1-91. Luxembourg. 2018. Available online: https://eur-lex.europa.eu/legal-content/EN/TXT/?uri=CELEX\%3A32018D0229 (accessed on 15 October 2019).

63. Poikane, S.; Herrero, F.S.; Kelly, M.G.; Borja, A.; Birk, S.; van de Bund, W. European aquatic ecological assessment methods: A critical review of their sensitivity to key pressures. Sci. Total Environ. 2020, 140075. [CrossRef]

64. Søndergaard, M.; Larsen, S.E.; Jørgensen, T.B.; Jeppesen, E. Using chlorophyll- $a$ and cyanobacteria in the ecological classification of lakes. Ecol. Indic. 2011, 11, 1403-1412. [CrossRef]

65. Boyer, J.N.; Dailey, S.K.; Gibson, P.J.; Rogers, M.T.; Mir-Gonzalez, D. The role of dissolved organic matter bioavailability in promoting phytoplankton blooms in Florida Bay. Hydrobiologia 2006, 569, 71-85. [CrossRef]

66. Lyche-Solheim, A.; Feld, C.K.; Birk, S.; Phillips, G.; Carvalho, L.; Morabito, G.; Mischke, U.; Willby, N.; Søndergaard, M.; Hellsten, S.; et al. Ecological status assessment of European lakes: A comparison of metrics for phytoplankton, macrophytes, benthic invertebrates and fish. Hydrobiologia 2013, 704, 57-74. [CrossRef]

67. Quintana, X.D.; Cañedo-Argüelles, M.; Nebra, A.; Gascón, S.; Rieradevall, M.; Caiola, N.; Sala, J.; Ibañez, C.; Sánchez-Millaruelo, N.; Boix, D. New tools to analyse the ecological status of Mediterranean wetlands and shallow lakes. In Experiences from Surface Water Quality Monitoring. The Handbook of Environmental Chemistry; Munné, A., Ginebreda, A., Prat, N., Eds.; Springer: Cham, Switzerland, 2015; Volume 42, pp. 171-199. [CrossRef]

68. Subida, M.D.; Drake, P.; Jordana, E.; Mavrič, B.; Pinedo, S.; Simboura, N.; Torres, J.; Salas, F. Response of different biotic indices to gradients of organic enrichment in Mediterranean coastal waters: Implications of non-monotonic responses of diversity measures. Ecol. Indic. 2012, 19, 106-117. [CrossRef]

69. Egertson, C.J.; Kopaska, J.A.; Downing, J.A. A century of change in macrophyte abundance and composition in response to agricultural eutrophication. Hydrobiologia 2004, 524, 145-156. [CrossRef]

70. Penning, W.E.; Mjelde, M.; Dudley, B.; Hellsten, S.; Hanganu, J.; Kolada, A.; van der Berg, M.; Poikane, S.; Phillips, G.; Willby, N.; et al. Classifying aquatic macrophytes as indicators of eutrophication in European lakes. Aquat. Ecol. 2008, 42, 237-251. [CrossRef] 